\title{
DISAPPEARING STOCK OPTIONS: THE EVOLUTION OF EQUITY PAY
}

\begin{abstract}
Gala Ades-Laurent*
Executive compensation has skyrocketed over the last thirty years, largely due to an increased use of equity pay. Corporations were able to generously compensate their top executives, and, at least in the short term, link executive pay to firm performance. Thanks to modifications to the tax code and accounting rules in 1993, public companies favored the grant of options over stock. Yet this produced perverse incentives, including excessive risk-taking and a heightened focus on short-term stock performance, which many commentators and policy-makers believed culminated in the 2008 financial crisis. In response, public resentment swelled, spurring academic debates, congressional hearings, and statutory changes.

This trend shifted in the past decade as companies now impel conservative behavior through executive compensation. This Note presents the first comprehensive study of the change in the equity composition of executive compensation after the financial crisis. For the first time, stock grants overtook options as the dominant form of equity pay. The evidence shows that the movement away from stock options is largely a response to the panoply of federal efforts to control 'excessive' executive compensation and mitigate risk. This finding has important implications for regulators and shareholders alike who wish to offset managerial influence over executive pay at public companies.
\end{abstract}

* J.D. Candidate 2017, Columbia Law School; B.A. 2013, University of Chicago. Many thanks to Professor Robert J. Jackson, Jr. for his invaluable insight and guidance throughout the process of writing this Note. Additional thanks to the superb staff and editorial board of the Columbia Business Law Review for their support in preparing this Note for publication. All errors are my own. 
I. Introduction 349

II. Federal Responses to the Use of Options in Executive Compensation

A. Change in Accounting Rules............................... 353

B. SEC Public Disclosure Rules .............................. 354

C. Amendments to the Tax Code.............................. 356

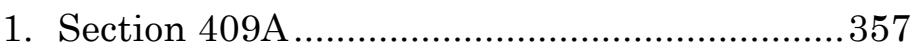

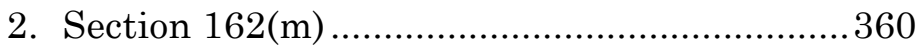

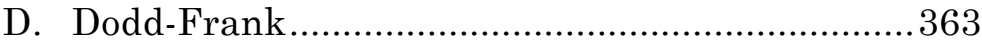

III. Evidence on the Distribution of Stock and Options Grants in Executive Compensation Packages...........366

A. Methodology .................................................. 367

B. Evidence on the Decline of Options Grants as Compensation 371

1. Aggregate Increase in Stock and Decrease in Option Compensation ................................ 371

2. Effects of CEO's Age on Equity Composition 374

3. Trends for CEOs............................................. 377

4. Firm Size .................................................... 381

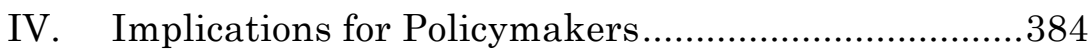

A. Risk-Taking for Executives..............................384

1. Risk-Taking: The Issue .................................385

2. Increased Shareholder Activism as a Consequence of Suboptimal Risk-Taking ...... 387

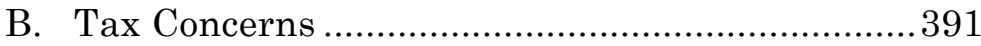

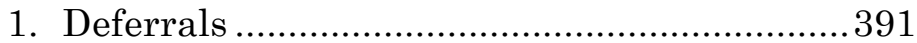

2. Deductions ..................................................... 392

3. Current Tax Reform Legislation .................... 394

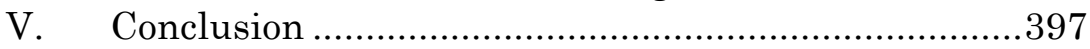




\section{INTRODUCTION}

For more than two decades, the pages of finance journals,${ }^{1}$ legislative hearings,${ }^{2}$ and academic dialogue ${ }^{3}$ have been filled with discussions of executive compensation in the United States' largest public companies. ${ }^{4}$ This is in large part due to the increased use of equity compensation after 1993, generally in the form of stock and stock-option grants. ${ }^{5}$ Equity pay is often emphasized as the key to improving executive accountability by linking pay to performance. After the profusion of accounting scandals in the early 2000s, Congress passed the Sarbanes-Oxley Act ("SOX") in order to overhaul the requirements for all public company boards, management, and public accounting firms. ${ }^{6}$ The uproar

1 See, e.g., New Concerns Arise on Executive Compensation, FinancIAL Times (May 27, 2006), http://find.galegroup.com.ezproxy.cul.columbia.edu /ftha/infomark.do?\&source=gale\&prodId=FTHA\&userGroupName=columb iau\&tabID=T003\&docPage $=$ article $\&$ docId $=$ HS2306375603\&type=multipag e\&contentSet=LTO\&version $=1.0$ (available by subscription at http://find.galegroup.com/ftha/index.jsp).

2 See, e.g., Executive Compensation How Much is Too Much: Hearing before the Committee on Oversight and Government Reform, 111th Cong. 1 (2009).

3 See, e.g., Richard Posner, Are American CEOs Overpaid, and, if So, What if Anything Should Be Done About It?, 58 Duke L. J. 1013 (2009); Michael C. Jensen \& Kevin J. Murphy, CEO Incentives-It's Not How Much You Pay, But How, Harv. Bus. Rev., May-June 1990, at 138; Susan Lorde Martin, Executive Compensation: Reining in Runaway AbusesAgain, 41 U.S.F.L. REV. 147 (2006).

4 A pervasive topic in the current academic debate over corporate governance is the question of whether U.S. executives are overpaid. The increase in average total CEO compensation between 1993-2000 climbed from $\$ 3.7$ million to $\$ 17.4$ million. See Lucian Bebchuk \& Yaniv Grinstein, The Growth of Executive Pay, 21 OxF. REV. ECON. PoL'y 283, 285 (2005).

5 In 1993, Congress eliminated the corporate income tax deduction for executive salaries over $\$ 1$ million, since the limitation was applicable only to non-incentive-based compensation. See Sanjai Bhagat \& Roberta Romano, Reforming Executive Compensation: Focusing and Committing to the Long-term, 26 YALE J. ON REG. 359, 361 (2009).

6 Sarbanes-Oxley Act of 2002, Pub. L. No. 107-204, 116 Stat. 745 (codified at 15 U.S.C. $\S \S 15,18$ ). The Act introduced new measures demanding more stringent disclosure rules, including an increased 
increased following the 2008 financial crisis, as the standard executive pay arrangements appeared to both reward executives for increases in short-term stock performance at the cost of long-term value and produce incentives for excessive risks. ${ }^{7}$ In response, Congress increased disclosure requirements for key financial services players and regulators through the Dodd-Frank Act. ${ }^{8}$

Today, perceptions of the response to the financial crisis vary. The goal of corporate governance reform, however, is undisputed: to better align executive interests with those of shareholders. ${ }^{9}$ Many academics, ${ }^{10}$ economists, ${ }^{11}$ and policy-

disclosure of off-balance-sheet transactions (\$401(j)), mandatory managerial certification of periodic reports (\$302), clawback provisions for incentive-based compensation ( $\$ 304)$, strengthened independence of the audit committee (§301), and enhanced requirements regarding auditor oversight and independence ( $\$ 101)$.

7 See, e.g., Lucian A. Bebchuk \& Jesse M. Fried, Paying for LongTerm Performance, 158 U. PA. L. REV. 1915, 1916-1918 (2010); John C. Bogle, The Executive Compensation System is Broken, 30 J. CoRP. L. 761, 764 (2005) ("Too often . . . our focus is only on the short-term, and governance is a long-term issue").

8 See infra Section II.

9 The board of directors is obligated to act in the interests of shareholders. Del. Code Ann. tit. 8 141(a) (1983). However, an agency problem exists because the interests of shareholders and directors frequently diverge. In public companies that lack a controlling shareholder, the problem is especially severe since directors of these companies often only own a small fraction of the firm's equity. See Lucian Arye Bebchuk et al., Managerial Power and Rent Extraction in the Design of Executive Compensation, 69 U. CHI. L. REV. 751, 761 (2002); Robert J. Jackson, Jr., Private Equity and Executive Compensation, 60 UCLA L. REV. 638, 641 (2013). Meanwhile, company executives have substantial power over whether the directors remain on the board. Simultaneously, most shareholders own too small an interest in the firm to make monitoring the decisions of directors worthwhile. Id. Thus, there is thus an agency problem inherent in the structure of corporations since directors have incentives to favor executive interests over shareholder interests.

10 See, e.g., Bebchuk \& Fried, supra note 7; Bebchuk \& Grinstein, supra note 4.

11 See John E. Core \& Wayne R. Guay, Is U.S. CEO Compensation Broken?, 17 J. APP. CORP. FIN. 96, 97 (2005) (discussing incentives to increase corporate efficiency and value, CEOs "have[e] greater incentives [to increase corporate efficiency and value] when his or her wealth is more 
makers ${ }^{12}$ agree that executive compensation packages should include an equity component that links pay to firm performance. Yet options and stock grants function very differently in terms of incentives and risk. ${ }^{13}$ For a variety of reasons, options are associated with heavier risk-taking, which some in Washington and academia believe led to the recent financial crisis. ${ }^{14}$ In response, companies impel more conservative behavior through executive pay, including an increased vesting period for equity pay and a greater use of restricted stock compared to options. ${ }^{15}$

This Note presents the first comprehensive study of the transformation of senior executive pay in public companies in the years after the financial crisis. ${ }^{16}$ The data presented here suggest that both executives and boards of public

sensitive to changes in a given performance measure, such as the company's stock returns.").

12 TARP and Executive Compensation Restrictions: Hearing Before the Congressional Oversight Panel, 111th Cong. 32 (2010), https://fraser.stlouisfed.org/docs/historical/fct/cop_hearing_20101021.pdf [https://perma.cc/WL9L-A9MT] (statement of Kenneth R. Feinberg, Special Master for TARP Executive Compensation, June 2009 through September 2010) (It is "[v]ery important that compensation be spread and not be guaranteed and be tied to the overall performance of the company where the official works.").

13 See infra Section III.

14 See, e.g., Murphy, supra note 7, at 851; David I. Walker, The Challenge of Improving the Long-Term Focus of Executive Pay, 51 B.C. L. REV. 435, at 438, 440, 443 (2010); Erica Beecher-Monas, The Risks of Reward: The Role of Executive Compensation in Financial Crisis, 6 VA. L. \& Bus. REv. 101, 111 (2011); Sharon Hannes \& Avraham Tabbach, Executive Stock Options: The Effects of Manipulation on Risk Taking, 38 J. CoRP. L. 533, 544-45 (2013); Press Release, Cong. Oversight Panel, Congressional Oversight Panel Examines Executive Compensation Restrictions in the Troubled Asset Relief Program (Feb. 10, 2011), https://fraser.stlouisfed.org/docs/historical/fct/cop/cop_pressrelease_201102 10.pdf [https://perma.cc/NY7T-ECDZ].

15 See, e.g., Posner, supra note 3, at 1045-46; Bhagat \& Romano, supra note 5, at 359; Bebchuk et al., supra note 9, at 828 .

16 I define "senior executives" as the chief executive officer ("CEO"), chief financial officer ("CFO"), and the three most highly compensated employees other than the CEO and CFO, in line with the current SEC rule for reporting. See infra note 80 . 
companies are moving away from compensation based largely on stock-option grants in favor of compensation based on stocks. The evidence also demonstrates that equity pay as a percentage of executive compensation packages has been increasing since 2010. This suggests a more conservative approach to executive compensation packages than there had been before the crisis.

These findings have important implications for the relationship between equity compensation and corporate risk-taking. They also offer lessons to the regulators now charged with writing new rules of public company executive pay. This Note proceeds as follows. Section I summarizes the rise in the use of option-based compensation and discusses Congressional and regulatory pay policies over the last two decades. Section II presents data on the composition of executive equity pay packages in public companies from 2006 to 2014. Section III discusses the implications of this study's findings for the current debate over corporate governance policies surrounding executive pay at public companies.

\section{FEDERAL RESPONSES TO THE USE OF OPTIONS IN EXECUTIVE COMPENSATION}

In 1992, average CEO compensation was $\$ 2.3$ million. ${ }^{17}$ Just over ten years later, in 2005, average CEO compensation had more than doubled to $\$ 5.5$ million. ${ }^{18}$ The rapid rise in CEO compensation correlates neatly with the growing use of stock options as a percentage of that compensation. ${ }^{19}$ The numbers for executives at Standard \& Poor ("S\&P") 500 companies soared at an even more staggering rate. ${ }^{20}$ This Section will focus on several broadreaching reforms in the past two decades that Congress and

17 Posner, supra note 3, at 1021.

18 Id. at 1022.

19 Bebchuk et al., supra note 9.

20 See, e.g., William W. Bratton, The Academic Tournament over Executive Compensation, 93 CALIF. L. REV. 1557, 1562 (2005) (showing that senior executive compensation grew to $\$ 9.4$ million by 2002 ). 
regulatory agencies levied in their attempts to curb corporate leadership abuses.

\section{A. Change in Accounting Rules}

Options used to be an advantageous form of compensation for firms for accounting reasons: unlike a salary, these awards were not treated as an expense on the company's books. $^{21}$ Consequently, option grants had no effect on earnings, no matter how much the executive received from exercising the options. This is significant because earnings drive stock prices. In 2004, however, the Financial Accounting Services Board ("FASB") eliminated this accounting advantage by requiring that all options be recorded as an expense. ${ }^{22}$ Two years later, the Securities Exchange Commission ("SEC") decided that the accounting rules for the taxation of stock-based compensation would be governed by the Statement of Financial Accounting Standards No. 123(R), Share-Based Payment ("FAS $\left.123(\mathrm{R}))^{\prime}\right){ }^{23}$

This decision was issued in response to concerns that methods under the prior rules (APB 25) did not result in an accurate representation of the "economic transaction" of granting stock options. ${ }^{24}$ Under APB 25, no compensation cost must be recorded in financial statements for stock options issued to employees if the exercise price is equal to or greater than the market price on the date of the grant. ${ }^{25}$ FAS

21 Jerry W. Markham, Regulating Excessive Executive Compensation -Why Bother?, 2 J. Bus. \& TECH. L. 277, 294 (2007).

22 Staff of Joint Comm. on Taxation, JCZ-39-06, Present LaW AND Background Relating to Executive Compensation 38-39 (2006), http://www.jct.gov/x-39-06.pdf [https://perma.cc/7TUA-CXQL] [hereinafter Finance Committee Hearing].

23 Id.

24 Id. at 38. Additionally, there were concerns that stock-based compensation should be accounted for using one method (rather than allowing companies to use either APB 25 or FAS 123(R)), and that the rules under FAS 123(R) are more consistent with those under the International Financial Reporting Standards. Id.

$25 \mathrm{Id}$. at 43. 
$123(\mathrm{R})$, in contrast, requires companies to measure compensation costs based on the award's fair value as of the grant date. ${ }^{26}$ Accounting for stock options under FAS 123(R) thus results in a greater compensation expense than under APB 25. Because the mandatory stock option expensing caused options to be comparatively more expensive, FAS 123(R) may have led companies to rely less heavily on stock options in the design of their executive compensation packages.

\section{B. SEC Public Disclosure Rules}

The SEC has sought to better enforce accountability in executive compensation through disclosure reforms; providing shareholders and other observers with more comprehensive information will enable them to make informed decisions. ${ }^{27}$ These reforms have followed a twisted path. In 1992, the SEC adopted rules that moved away from disclosures in narrative form and back to using tables that permitted comparability from year to year. ${ }^{28}$ Yet the strength of the tables' clarity and comparability was also their weakness: they were "highly formatted and rigid," preventing information that was not specifically mandated from being included in the tables. ${ }^{29}$ On July 26, 2006, the SEC amended the disclosure rules for executive compensation to provide for enhanced Summary

$26 I d$. at 38-39. To estimate the value of the options, the company must use option-pricing models that take into account the exercise price of the option, the expected option term, the current price of the underlying shares, the expected volatility of the price, the expected dividends, and the risk-free interest rates. The Joint Committee on Taxation suggests the binomial option-pricing model or the Black-Scholes-Merton option-pricing formula. $I d$.

27 Lucian Bebchuk \& Jesse Fried, Pay Without Performance: The Unfulfilled Promise of Executive Compensation, 192-94 (Harv. Univ. Press ed., 2004).

28 Executive Compensation and Related Person Disclosure, 71 Fed. Reg. 53,158, 53,160 (Sept. 8, 2006) (to be codified at 17 C.F.R. pts. 228, 229, 232, 239, 240, 245, 249, 274).

29 Id. at 53,161 . 
Compensation and Director Compensation tables, along with a narrative overview consisting of a general discussion and analysis of the compensation. ${ }^{30}$ The SEC's stated purpose was to provide investors with a "more complete and useful disclosure" regarding executive compensation. ${ }^{31}$

Furthermore, the SEC announced that it would align the reporting of equity awards with the FAS 123(R) requirements. ${ }^{32}$ In furtherance of this objective, the SEC made the following revisions. First, the SEC revised the dollar values in the "Stock Awards" and "Options Awards" columns of the Summary Compensation and Director Compensation tables to disclose the compensation cost of the awards, before reflecting forfeitures, as described in FAS 123(R). ${ }^{33}$ Second, the SEC revised the tabular presentation of option grants to require disclosure of the grant date fair value, the FAS 123(R) grant date, the closing market price on the grant date if greater than the exercise price, and the date the compensation committee took action to grant the award if different from the grant date. ${ }^{34}$ Third, the SEC revised the calculation for the value of both stock and options grants to be determined by the grant date fair value, rather

$30 I d$. at 53,162. The narrative overview provides information about the company's compensation objectives, policies, procedures, and processes. It must include the objectives of the compensation program, what the compensation program is designed to reward, each element of the compensation, why the company chooses to pay for each element, how the company determines the amount for each element, and how each element fits into the company's overall compensation objectives. These disclosure rules apply to the $\mathrm{CEO}, \mathrm{CFO}$, and three other highest paid executives other than the CEO and CFO. See Press Release, SEC, SEC Amends Executive Compensation Disclosure to More Closely Align with FAS 123R (Dec. 22, 2006), https://www.sec.gov/news/press/2006/2006-219.htm [https://perma.cc/9LVD-L3CB].

31 Executive Compensation Disclosure, 71 Fed. Reg. 78,338, 78,338 (Dec. 29, 2006) (to be codified at 17 C.F.R. pts. 228, 229).

32 Id.

$33 I d$. The forfeitures must be described in a footnote. $I d$.

34 Press Release, SEC, SEC Votes to Adopt Changes to Disclosure Requirements Concerning Executive Compensation and Related Matters (Jul. 26, 2006), https://www.sec.gov/news/press/2006/2006-123.htm [https://perma.cc/WDY7-ZK3C]. 
than the number of securities. ${ }^{35}$ Fourth, the SEC revised the Grants of Plan-Based Awards Table to require disclosure of the grant date fair value of each individual equity award. ${ }^{36}$ Finally, the SEC made revisions requiring the company to discuss in the narrative disclosure the timing of the grant date of the stocks regarding the release of material information. ${ }^{37}$ As with the changes in accounting rules, the revised disclosure rules have made options an increasingly expensive choice for companies.

\section{Amendments to the Tax Code}

Congress has long used the federal tax code to limit the amount and type of executive compensation. Proponents of enhanced executive accountability argue that tax-based initiatives are a good way to make compensation structures more performance based. ${ }^{38}$ This is not surprising given the tax implications for executives and corporations regarding these payments. Critics, however, argue not only that such tax provisions are ineffective at reducing executive

35 Executive Compensation and Related Person Disclosure, 71 Fed. Reg. at 53,171-72. The only change is that the awards are disclosed in dollars, rather than the number of units or shares, but this provides shareholders with a more accurate and current estimation of the value of the compensation package when granted to the highest paid executive officers. Id. at 53,172.

$36 I d$. at 53,179 . This is important because it required disclosure of any stock or option appreciation right that was repriced or materially modified during the last completed fiscal year, including the incremental fair value that was computed as of the repricing or modification date. The objective is to give shareholders a clear and current picture of the executive compensation package. Executive Compensation Disclosure, 71 Fed. Reg. at 78,338.

37 Executive Compensation and Related Person Disclosure, 71 Fed. Reg. at 53,163. Examples include a grant date immediately prior to the release of significant positive earnings or a new product development. Id. While the SEC does not comment on whether it is good or bad practice to time grant dates, its disclosure requirement appears to be in line with an attempt to prevent options backdating.

38 Kathryn J. Kennedy, Excessive Executive Compensation: Prior Federal Attempts to Curb Perceived Abuses, 10 Hous. Bus. \& TAX L.J. 196, 199 (2010). 
compensation levels, but also that they impose a variety of unexpected costs. ${ }^{39}$ Two sections in the code that target executive compensation are discussed below: Section 409A and Section $162(\mathrm{~m}){ }^{40}$

\section{Section $409 \mathrm{~A}$}

On October 22, 2004, President George W. Bush signed the American Jobs Creation Act of 2004, creating Section $409 \mathrm{~A}$ of the Internal Revenue Code. ${ }^{41}$ This section implemented sweeping changes to the tax law applicable to nonqualified deferred compensation ("NQDC") plans, which often consist of non-qualified stock options ("NQSO"). ${ }^{42}$ Employers often use NQDC plans to induce certain behavior. For instance, a company may condition that certain compensation will be paid only if the executive remains with the company for a specified number of years. The company may also require the deferral of certain compensation in

39 See generally Andrew C.W. Lund, Tax's Triviality as a PayReforming Device, 57 VILL. L. REV. 571 (2012); Joy Sabino Mullane, Incidence and Accidents: Regulation of Executive Compensation Through the Tax Code, 13 Lewis \& ClarK L. REV. 485 (2009); Susan J. Stabile, Is There a Role For Tax Law in Policing Executive Compensation?, 72 ST. JoHN's L. REV. 81 (1998); Kennedy, supra note 38.

40 These examples are not exhaustive but an extensive analysis of the tax code is beyond the scope of this Note. Another example includes restrictions on the terms of golden parachute payments. See I.R.C. §280G (2012); I.R.C. § 4999 (2012).

41 American Jobs Creation Act of 2004, Pub. L. No. 108-357, § 885, 118 Stat. 1418 (2004).

42 An NQDC plan is an arrangement between an employer and one or more employees to defer the receipt of currently earned compensation. I.R.C. $\S 409 \mathrm{~A}$ applies to any plan providing for a deferral of compensation other than a qualified employer plan. Qualified employer plans include tax-qualified retirement plans (I.R.C. § 401(a) qualified plans, 457(b) plans, 403(a) and (b) annuity plans, SEPs, SIMPLEs, and government excess benefit arrangements under I.R.C. $\S 415(\mathrm{~m})$ ) —or a bona fide vacation, sickness, disability, and death benefit plan. Finance Committee Hearing, supra note 22 , at 20. 
order to comply with the Section 162(m) limitation on the deductibility of compensation in excess of $\$ 1$ million. ${ }^{43}$

Section 409A was the first rule that specifically governed the tax treatment of NQDC plans. ${ }^{44}$ Section 409A provides that amounts deferred under an NQDC plan will be includible in income and subject to an additional $20 \%$ excise tax. ${ }^{45}$ Simply put, Section 409A penalizes improper deferrals of compensation by imposing heavy tax consequences. The rule's objective is to eliminate abuses related to election timing, distribution timing, and the ability to take accelerated payments under such plans. ${ }^{46}$ The IRS issued guidance under 409A in Notice 2005-1 released on December

43 See infra Section II.C.2, Section IV.B.2.

44 Finance Committee Hearing, supra note 22, at 19. Incentive stock options ("ISOs," or statutory stock options) receive a more beneficial tax treatment than do NQSOs, but there are several requirements that the plan must meet to qualify as an ISO. These requirements, which are listed in I.R.C. $\S 422(\mathrm{~b})$, include the following: options must be exercised within 10 years of their grant; they must be nontransferable except by death; the employee must remain with the employer; at least two years must lapse between the grant date and the employee's sale of the stock; and at least one year must lapse between the exercise date and the sale of the stock. Furthermore, I.R.C. $\$ 422(\mathrm{~d})$ sets a $\$ 100,000$ annual limit on the aggregate value of the stock that any one executive can acquire by exercising ISOs. If any of these requirements are not met, the stock options will be taxed as an NQSO plan. ISOs never generate deductions for employers, and the employee's income will not be taxed until sold, with the difference between the sale price and the exercise price taxed as a capital gain. Daniel L. Slaton, Solving Stock Option Compensation: Why Book Tax Conformity May Not Be the Answer, 9 Hous. Bus. \& TAx L. J. 175, 190 (2008). The difficulty in meeting the requirements of I.R.C. $\S \S 422(\mathrm{~b})$ and (d), however, prevents many companies from receiving the ISO tax advantages. See, e.g., Gary Cvach \& Terri Stecher, Incentive Stock Options-Navigating the Requirements for Compliance, KPMG: What's News in Tax (May 2, 2016), https://home.kpmg.com/content/dam/kpmg/pdf/2016/05/tnf-wnit-iso-may-22016.pdf [https://perma.cc/KR4D-GFHC].

45 Finance Committee Hearing, supra note 22, at 19.

46 American Jobs Creation Act of 2004, Pub. L. No. 108-357, 118 Stat. 1418 (2004). 
20, 2004 and gave taxpayers until December 31, 2005 to bring their documents into compliance. ${ }^{47}$

An important feature of Section 409A is its impact on equity awards. ${ }^{48}$ Prior to Section 409A's prescript, executives engaged in options backdating to a grant or exercise date at which the underlying stock price was lower in order to imperil benefits, resulting in an underpayment of taxes. ${ }^{49}$ Under Notice 2005-1, however, non-discounted stock options (which are granted at a price above the fair market value of the stock on the date of the grant) are not considered NQDC under Section 409A, and thus are not subject to its requirements. ${ }^{50}$ However, a discounted option with an exercise price below the fair market value of the stock at the date of the grant is subject to the rules under 409A. ${ }^{51}$ Thus, a backdated option would likely be treated as a NQDC plan and subject to the requirements of Section 409A, such as the income exclusion, the $20 \%$ excise tax, and interest at the rate applicable to underpayments of the tax plus one percentage

47 I.R.S. Notice 2005-1, 2005-1 C.B. 274, https://www.irs.gov/pub/irsdrop/n-05-01.pdf [https://perma.cc/8B8T-M9B8].

48 The conference report for I.R.C. $\S 409$ A does not mention restricted stock, but the Treasury regulations separately exclude restricted property from the reach of $\S 409 \mathrm{~A}$, stating that "there is no deferral of compensation merely because the value of the property [received] is not includible in income by reason of the property being substantially nonvested." Treas. Reg. § 1.409A-1(b)(6)(i) (2008).

49 The backdating of option exercises has similar implications: here, the company is misrepresenting the date at which the option is exercised to make it appear that the exercise occurred at an earlier date-and lower price-than when the exercise actually occurred. Thus, executives can backdate the exercise date to correspond with the low point of the closing price of the company's stock, thereby minimizing the gain reported as ordinary income. Furthermore, because any additional gain to the executive is treated as a capital gain when the stock is held for a year prior to sale, the executive can maximize the capital gain treatment of any eventual profit by starting the clock early on the holding period. Christopher Cox, Testimony Concerning Options Backdating, SEC (Sept. 6, 2006), https://www.sec.gov/news/testimony/2006/ts090606cc.htm [https://perma.cc/5RD3-2S7T].

50 I.R.S. Notice 2005-1, supra note 47.

51 Finance Committee Hearing, supra note 22, at 32. 
point. $^{52}$ Consequently, the tax treatment for option compensation under Section 409A may make stock option backdating less advantageous, therefore further eliminating the preference for options.

\section{Section $162(\mathrm{~m})$}

Proponents of using the tax code to better link pay with performance in executive compensation have also concentrated on tax benefits, such as the deductibility of wages. ${ }^{53}$ Normally, executive salaries, like employee wages, are deductible business expenses. ${ }^{54}$ Section $162(\mathrm{~m})$, however, limits the tax deductibility of compensation to $\$ 1$ million, whether paid in cash or otherwise. ${ }^{55}$ Simultaneously, companies are permitted to deduct the cost of executive salaries only so long as such salaries qualify as "performance-based compensation." 56 The objective is to ensure that companies reform their executive compensation schemes to better link pay with performance, shifting from fixed compensation plans (which are not deductible) to performance-based plans (which are).

To qualify for the "performance-based" exception to the $\$ 1$ million limitation, the compensation must be paid solely on account of the executive's attainment of performance goals as determined by an objective formula. ${ }^{57} \mathrm{~A}$ compensation

52 Id. at 41.

53 See I.R.C. § 162(a) (2012) ("There shall be allowed as a deduction all the ordinary and necessary expenses paid . . . in carrying on any trade or business, including (1) a reasonable allowance for salaries").

54 Finance Committee Hearing, supra note 22, at 3.

55 I.R.C. $\S 162(\mathrm{~m})(1)$ (2012) ("In the case of any publicly held corporation, no deduction shall be allowed ... with respect to any covered employee to the extent that the amount of such remuneration for the taxable year with respect to such employee exceeds $\$ 1,000,000 . ”)$.

56 See I.R.C. $§ 162(\mathrm{~m})(4)(\mathrm{C})(2012)$ (the limits on deductibility "shall not include any remuneration payable solely on account of the attainment of one or more performance goals").

57 See I.R.C. $\S 162(\mathrm{~m})(4)(\mathrm{C})(\mathrm{i})$-(iii). This can include stock price, market share, sales, costs, and earnings, and it can be applied at the level 
committee of two or more independent directors must establish the performance goal, and then a majority of the shareholders must approve it. ${ }^{58}$ Finally, before the payment is made to the executive, the compensation committee must certify that the performance goals have been met. ${ }^{59}$

Stock options or stock appreciation rights meet the exception, no matter how large, since the amount of compensation attributed to the options is based solely on the increase in the stock price. This increase displays a clear improvement in the corporation's performance. ${ }^{60}$ Grants of restricted stock, on the other hand, are not considered inherently performance-based because the executive will receive the compensation even if the stock price decreases or stays the same. Thus, restricted stock is treated like cash compensation and will not satisfy Section 162(m) unless the grant or vesting of the restricted stock is based on the attainment of performance goals. In effect, "the expected payoffs on restricted stock ... are less sensitive to share price movements than the payoffs for ... options." ${ }^{\prime \prime}$ As a result, Section $162(\mathrm{~m})$ makes stock options relatively less expensive than base salaries, bonuses, or stock grants-all of which are subject to the $\$ 1$ million cap. ${ }^{62}$

of the individual, business unit, or corporation. Finance Committee Hearing, supra note 22 , at 4 .

58 I.R.C. $\S \S 162(\mathrm{~m})(4)(\mathrm{C})(\mathrm{i})-(\mathrm{ii})(2012)$.

59 I.R.C. $\S 162(\mathrm{~m})(4)(\mathrm{C})(\mathrm{iii})(2012)$.

60 I.R.C. $\S 162(\mathrm{~m})(4)(\mathrm{G})$ (2012) (unless the exercise price is less than the fair market price of the stock at the time of the grant). Treas. Reg. $\S 1.162-27(\mathrm{e})(2)(v i)$ ("Compensation attributable to a stock option or a stock appreciation right is deemed [fully deductible if] the amount of compensation the employee could receive is based solely on an increase in the value of the stock after the date of the grant or award.").

61 David I. Walker, The Non-Option: Understanding the Dearth of Discounted Employee Stock Options, 89 B.U.L. REV. 1505, 1535 (2009).

62 I.R.C. $\S 162(\mathrm{~m})$ (2012). These tax changes only applied to the most senior executives-the CEOs and the other four highest paid employees. I.R.C. $§ 162(\mathrm{~m})(3)$ (2012). After the SEC amended its disclosure requirements under the Securities Exchange Act in 2006 to include individuals serving as the principal executive officer, the principal financial officer, and the three highest compensated executives other than the two aforementioned, the IRS issued new guidance that changes the 
Moreover, Section 162(m) favors certain types of options: if the executive receives option grants with an exercise price equal to or greater than the market price, then the options are presumed to be performance-based. This is because the compensation ultimately received is based solely on an increase in the value of the stock after the date of the grant. ${ }^{63}$ A discounted stock option, with an exercise price below the market price, however, has value immediately, so it cannot be described as "performance-based." Thus, at-themoney options receive more favorable tax treatment, since they fall under the exception to the $\$ 1$ million limitation. As discussed in Section I.C.1 supra, executives may backdate options to the lowest price of the underlying stock in order to

group of covered employees subject to the compensation deduction limit under Section $162(\mathrm{~m})$. Under the new rules, the company's CFO will never be subject to Section $162(\mathrm{~m})$, even if the CFO is one of the most highly compensated officers. I.R.S. Notice 2007-49, 2007-1 C.B. 1429, https://www.irs.gov/pub/irs-drop/n-07-49.pdf [https://perma.cc/ZS7EQ44K]. Furthermore, the total number of officers in addition to the CEO who are subject to Section $162(\mathrm{~m})$ was reduced from four to three. $I d$. at 3 . This change is intended to resolve the conflict between the 2006 amended SEC disclosure rules and Section 162(m). While the amended disclosure rules continue to require disclosure for five executive officers, two are now covered by the rules based on their positions, and three are covered based on their level of compensation. In contrast, a covered employee under Section $162(\mathrm{~m})$ consists of one executive officer based on her position and four based on their level of compensation. Id. The interpretation specifically provides that the principal financial officer is not included as a covered employee, and as a result, is not subject to the Section $162(\mathrm{~m})$ deduction limitation. $I d$. at 4 .

63 The conference report for I.R.C. $§ 162(\mathrm{~m})$ describes:

Stock-based compensation is not treated as performancebased if it is dependent on other factors other than corporate performance. For example, if a stock option is granted to an executive with an exercise price that is less than the current fair market value of the stock at the time of the grant, then the executive would have the right to receive compensation on the exercise of the option even if the stock price decreases or stays the same. Thus, [such] options ... do not meet the requirements for performancebased compensation.

Finance Committee Hearing, supra note 22, at 5. 
avoid detrimental tax consequences. Yet the imposition of Section $162(\mathrm{~m})$ provides that discounted stock options will not be subject to the deduction, further reducing their appeal to company boards.

\section{Dodd-Frank}

The economic collapse of 2008 focused the spotlight back on executive compensation, prompting questions about better ways to structure pay in order to balance firms' longterm interests with executives' demands. Yet the government's stimulus package only heightened the public fervor surrounding executive compensation. Although the Federal Reserve provided an $\$ 85$ billion bailout to American International Group (AIG), the firm was still permitted to pay $\$ 165$ million in retention bonuses to its executives. ${ }^{64} \mathrm{In}$ 2010, Congress passed the Dodd-Frank Wall Street Reform and Consumer Protection Act. ${ }^{65}$ Title IX contains seven sections designed to mandate various changes in corporate governance matters. ${ }^{66}$ The goal of the Act's passage is to "promote the long-term sustainability of the U.S. financial system" by "protect[ing] investors, enhanc[ing] market stability, and promot[ing] capital formation." 67

Although Dodd-Frank took effect on July 21, 2010, the SEC only recently proposed a rule with regard to Section

64 Bhagat \& Romano, supra note 15, at 360. Note that these were not merit bonuses, based on performance, but retention bonuses that enabled the executives to safely unwind the credit default swaps in a timesensitive manner.

65 See Dodd-Frank Wall Street Reform and Consumer Protection Act of 2010, Pub. L. No. 111-203, 124 Stat. 1376 (2010) (codified as amended in scattered sections of the U.S. Code).

$66 I d$. These seven sections consist of $\S \S 951$ (shareholder approval of executive compensation, or "say-on-pay"), 952 (compensation committee independence), 953 (executive compensation disclosures), 954 (compensation clawbacks), 955 (employee and director hedging disclosure), 956 (compensation structure reporting), and 957 (broker voting).

67 Mary Jo White, Statement on the Anniversary of the Dodd-Frank Act, SEC (July 16, 2015), https:/www.sec.gov/news/statement/statementon-the-anniversary-of-the-dodd-frank-act.html [https://perma.cc/2Z3GTWXK]. 
953(a) ("Disclosure of Pay Versus Performance") on April 29, 2015. ${ }^{68}$ Section 953(a) adds Section 14(i) to the Securities and Exchange Act and seeks to coordinate "the relationship between executive compensation actually paid and the financial performance of the issuer, taking into account any change in the value of the shares of stock and dividends of the issuer and any distributions." ${ }^{\circ 9}$ Specifically, it calls for the SEC to devise rules requiring a company to provide in its annual proxy statement a "clear description," which may include a "graphic representation," to show the "relationship between executive compensation actually paid and the financial performance of the issuer."70 According to a proposal the SEC released for comment in April 2015, companies will be required to disclose the relationship between executive pay and performance, starting with 2016 annual schedule $14 \mathrm{~A}$ and schedule $14 \mathrm{C}$ proxy and solicitation statements issued prior to shareholder meetings. ${ }^{71}$ This rule, if accepted, will require the reporting of bonuses and other compensation actually paid out (as opposed to accrued or vested) for the previous five fiscal years to the company's $\mathrm{CEO} ;{ }^{72}$ it will be listed in a table alongside the share performance of the company and its peers. $^{73}$

While President Obama described Dodd-Frank as "the toughest financial reform since the ones we created in the aftermath of the Great Depression," ${ }^{44}$ Section 953 was not

68 Press Release, SEC, SEC Proposes Rules to Require Companies to Disclose the Relationship Between Executive Pay and a Company's Financial Performance (Apr. 29, 2015), https://www.sec.gov/news/press release/2015-78.html [https://perma.cc/P44T-GHJV].

69 Dodd-Frank Act § 953(a)(i).

70 Id.

71 Press Release, SEC, supra note 68.

72 Id. ("The amount disclosed for the remaining executive officers would be the average compensation actually paid to those executives.").

73 Pay Versus Performance, 80 Fed. Reg. 26,330, 26,332 (proposed May 7, 2015) (to be codified at 17 C.F.R. pts. 229, 240).

74 Obama's Remarks on the Financial Deal, N.Y. Times (June 25, 2010), http://www.nytimes.com/2010/06/26/us/politics/26regulate-text.html [https://perma.cc/XNA6-YNU9]. 
without its detractors. The Center on Executive Compensation found that the provision is "unprecedented in [its] vagueness and breadth" and fails to specify the measure of comparison for what is "actually paid." 75 The Center argued that this provision has the unintended consequence of encouraging short-term financial performance, rather than rewarding strategies that increase long-term shareholder value. ${ }^{76}$

It is too early to analyze the effects of Section 953 on executive compensation suites, since its application begins with the 2016 annual schedules. ${ }^{77}$ One foreseeable problem is the difficulty in matching long-term incentive awards with appropriate periods of financial performance. The rule states that equity awards would be considered "actually paid" on the date of vesting-even if, in the case of stock options, they have yet to be exercised-and valued at their fair value on the vesting date, computed under FASB $123(\mathrm{R}) .{ }^{78}$ Yet Section 953(a), by requiring the vesting date value of a stock option to be reported at fair value, ${ }^{79}$ will result in more compensation actually paid. This is because an option's fair value almost always exceeds its intrinsic value and an "outof-the-money" option has some fair value (but no intrinsic

75 Letter from Timothy J. Bartl, Senior Vice President and General Counsel, Center on Executive Compensation, to Elizabeth M. Murphy, Secretary, SEC (Sept. 1, 2010) at 1-2, http://www.execcomp.org/Docs/c1041\%20COEC\%20Comments\%20on\%20Exec\%20Comp\%20in\%20Title\%20I

X\%20Dodd-Frank.pdf [https://perma.cc/7RMS-KGYQ] (Comments on Executive Compensation and Governance Provisions in Title IX, Subtitle E of the Dodd-Frank Wall Street Reform and Consumer Protection Act). This refers to the Senate-passed version of the bill, which is identical to the final provision in Dodd-Frank.

76 Id. at 2. See also Jeffrey N. Gordon, "Say on Pay": Cautionary Notes on the U.K. Experience and the Case for Shareholder Opt-In, 46 HARV. J. ON LEGIS. 323 (2009) (providing an in-depth analysis of the problems associated with a mandatory say-on-pay regime in the United Kingdom).

77 Press Release, SEC, supra note 68.

78 Pay Versus Performance, 80 Fed. Reg. at 26,339.

79 This is in contrast to intrinsic value, which is the excess, if any, of the aggregate value of the shares underlying the option minus the aggregate exercise price of the option. 
value). Thus, Dodd-Frank has the effect of reducing optionbased compensation.

\section{EVIDENCE ON THE DISTRIBUTION OF STOCK AND OPTIONS GRANTS IN EXECUTIVE COMPENSATION PACKAGES}

The stark rise in the use of stock option grants and corresponding increase in corporate scandals attracted attention from federal agencies to curb perceived abuseslargely at the expense of option compensation. Indeed, the evidence in this Section suggests that since 2009, there has been an aggregate increase in stock compensation and decline in option compensation. This Section describes the design of current senior executive equity pay packages at over 3,300 publicly traded companies in the United States and the evolution of equity pay from 2006 to 2014 . Specifically, this Section investigates (1) the evolution of the composition of senior executive equity compensation; (2) the variations in equity pay arrangements by CEO age; and (3) the variations in equity pay arrangements by firm size.

In line with SEC disclosure requirements, companies must divulge compensation details for the five most senior executive officers in their proxy statements. ${ }^{80}$ By drawing on these filings, this Note provides the first systematic study of the evolution of equity pay arrangements across a broad spectrum of companies in the years after 2006. The underlying hypothesis is that following the onslaught of Congressional actions in the early 2000s that caused options to be comparatively expensive, companies responded by increasing the weight of stock grants in pay packages.

80 Executive Compensation and Related Person Disclosure, 71 Fed. Reg. 53,158, 53,241 (Sept. 8, 2006) (to be codified at 17 C.F.R. pts. 228, 229, 232, 239, 240, 245, 249, 274). As discussed in Section II, the current SEC rule requires disclosure for the $\mathrm{CEO}, \mathrm{CFO}$, and the three most highly compensated employees other than the CEO and CFO. The prior rule (before 2007) mandated disclosure for the CEO and the four most highly compensated employees other than the CEO. In most firms, however, the same executives are covered by either rule. 
A. Methodology

This study used data from S\&P's Compustat database, obtained through Wharton Data Research Services. ${ }^{81}$ The analysis begins with 2006 because the data for stock grants and total compensation are not directly comparable in the periods before and after 2006. Briefly, beginning in 2006, Compustat accounted for the grant date fair value of stock and option awards, as well as the annualized expense associated with the award. Under the 2006 reporting format, the variable STOCK_AWARDS_FV included all stock awards (time-vested restricted stock, performance-vested restricted stock, and performance shares) and the variable OPTIONS_AWARDS_FV included all option awards (traditional stock options, performance-vested options, and stock appreciation rights ("SARs")). ${ }^{82}$ Prior to the FAS 123(R) accounting requirements levied in 2006, the variable OPTION_AWARDS_BLK_VALUE used Black-Scholes methodology to generate the value of the options grants. ${ }^{83}$

81 Wharton Research Data Service, WhaRTon, UnIV. OF PA., https://wrds-web.wharton.up-enn.edu/wrds (last visited Apr. 8, 2017). S\&P's Compustat database includes executive compensation data extracted from the proxy statements of over 3,300 active and inactive firms in the S\&P 1500 index, plus a handful of additional firms. Data are compiled from annual company proxy statements filed with the SEC within 120 days of the company fiscal year end. Compensation data for the top five executives are typically reported each year, giving rise to details on over 39,000 executives. Occasional data entry errors exist, and several egregious outliers were removed (for example, the listing of TDC1 (the marker for total compensation) for both Jan Koum of Facebook in 2014, and Jeffrey Katzenberg of Dreamworks in 2006, as "0.001"), yet there is no better way to code such an immense amount of data. Any errors that remain are the fault of the author.

82 A SAR provides the recipient with the right to receive the amount of the increase in value of employer stock during a specified period. The recipient will receive the increase in value by exercising the SAR. Variations among SARs may include limitations on exercise until certain objectives are met, or the allowance of the proceeds of the SAR to be paid in stock rather than cash. Finance Committee Hearing, supra note 22, at 42 .

83 The Black-Scholes formula is one of the most well known models for valuing option pricing. It uses five inputs: strike price, stock price, time 
For stock, the equivalent pre-2006 variable was RSTKGRNT, which did not include the value of performance shares. Instead, performance shares were included in LTIP (longterm incentive plans), along with long-term non-equity plan awards.

The inconsistency in the calculation of options carried over to the total compensation variable TDC1. Before 2006, TDC1 included salary, bonus, other annual compensation, the grant date value of restricted stock (not including performance shares), the grant date value of options and SARs (based on the Black-Scholes methodology), long-term incentive plan payouts (including performance shares), and other total compensation. The 2006 version of TDC1 includes salary, bonus, non-equity incentive plan payouts, grant date value of stock (including performance shares) and options (including SARs), deferred compensation earnings, and other compensation. Consequently, as these two measures are not directly comparable, this Note only analyzes the composition of executive pay packages in the years after 2006 .

The calculation of various equity pay instruments has evolved over the last decade, largely due to changes in accounting rules and SEC disclosure rules. The fundamental composition of equity pay, however, has not changed. ${ }^{84}$ Thus, in the analysis that follows, "stock" includes time-vested restricted stock, ${ }^{85}$ performance-vested restricted stock, ${ }^{86}$ and

until expiration, volatility, and risk free interest rate. Proxy Statements Not Required to Value Option Grants to Outside Directors, 9 RIA PENSION \& Benefits WeEK Newsletter 22 (2003).

84 For example, calculating by the grant date, rather than the exercise date. See supra Part I.

85 Time-vested restricted stock is the conventional stock compensation plan: compensation in the form of company stock. The executive does not secure the stock immediately, but receives it according to a vesting plan and distribution schedule if she remains with the employer for a designated length of time. The most common period of vesting is three years. See generally The 2015 Top 250: Long-Term Incentive Grant Practices for Executives, FREDERICK W. COOK \& Co., INC. 4 (2015), http://www.fwcook.com/content/Documents/Publications/FWC_2015_Top_2 50.pdf [https://perma.cc/2YST-4AVM]. Restricted stock may be granted in two forms. The first is an award, in which the executive owns the shares 
performance shares (also known as phantom stock units). ${ }^{87}$ The category of "options" refers to conventional employee stock options (including both nonqualified stock and incentive stock options), ${ }^{88}$ performance-vested stock

outright, but may not take full ownership rights until after the vesting requirements are met. Second, she may receive stock in the form of a unit, in which the actual stock is not issued until the vesting requirements are satisfied. If the shares fail to vest, the award is forfeited. Carol Meyers Edelstein, Long-Term Incentives for Management, Part 4: Restricted Stock, 13 Compensation \& Benefits Rev. 30 (1981).

86 Performance-vested restricted stock mandates that in addition to the retention requirements, the executive must achieve certain stated performance milestones. Like time-vested restricted stock, performancevested restricted stock may also come in the form of awards or units. See David I. Walker, Evolving Executive Equity Compensation and the Limits of Optimal Contracting, 64 VAND. L. REV. 611, 631-32 n.65 (2011).

87 A performance share, or "phantom stock unit," is a restricted stock share (or unit) that vests upon the achievement of company-specified performance conditions. After the share vests, the executive will receive payment in either cash or shares of common stock (at a one-to-one ratio with each phantom stock unit), plus any dividends that accrued from the grant date until the vesting period. The difference between performance shares and performance-vested restricted stock is insignificant, economically-speaking. Id. at 631-32 n.66.

88 A stock option is the right, but not the obligation, to purchase a company's stock at a fixed price for a fixed period of time. The primary difference between the two types of stock options-non-qualified stock options and incentive stock options-lies in their tax treatment. See supra Section II.C.1. Recall that ISOs are only available to employees and limited to $\$ 100,000$. Id . at n.43. No income is reported when the option is exercised and the entire gain from the sale of the stock is taxed as longterm capital gains. Nonqualified stock options ("NSOs") are options granted in unlimited amounts that do not receive the same tax-favored treatment as ISOs. After exercise, the difference between the fair market value on the exercise date and the grant date price is reported as ordinary income. Gains (or losses) from the sale of the stock after exercise will be recorded as a capital gain (or loss). Because there is no limit on the amount of options that can be offered, NSOs will more likely compensate senior executives. Additionally, employers generally prefer NSOs because they may take a tax deduction stemming from what the recipient includes in her income. When "options" are discussed, NSOs tend to be the options under discussion. James M. Bickley, Employee Stock Options: Tax Treatment and Tax Issues, Cong. RESEArch SERv. 3 (2012), 
options, ${ }^{89}$ and SARs. ${ }^{90}$ The vast majority of options issued are conventional options, in turn dominated by nonqualified stock options ("NSOs"). ${ }^{91}$ Additionally, "[a]lmost all compensatory options issued by U.S. firms have been 'at-themoney' options," meaning that the strike price is set equal to the fair market value of the company's stock at the date of the option grant. ${ }^{92}$ Discounted, or "in-the-money" options, have rarely been observed and have dwindled to zero instances in recent years ${ }^{93}$ largely due to a tougher stance on tax rules by the IRS. ${ }^{94}$ Thus, the data included in this Note on executive pay packages in public companies

http://digitalcommons.ilr.cornell.edu/cgi/viewcontent.cgi?article=1935\&con text=key_workplace [https://perma.cc/5APZ-3LD7].

89 Id. Performance-vested stock option plans are analogous to performance-vested restricted option plans: in addition to the traditional retention criteria, the recipient will realize no value from the option unless the specified performance conditions are met. See Walker, supra note 86, at 631 n. 65 .

90 See Finance Committee Hearing, supra note 22, at 42.

91 See Bickley, supra note 88, at 8; see also Frederic W. Cook \& Co., INC., THE 2010 ToP 250, at 1, 22 (2010), http://www.fwcook.com/content/Documents/Publications/The_2010_Top_25 0_Report.pdf [https://perma.cc/E4CF-HVBB].

92 See Walker, supra note 61, at 1507.

93 In a study of options granted to CEOs of 1000 companies in 1992, Kevin Murphy found that only three percent were issued in-the-money. Kevin J. Murphy, Executive Compensation, in 3B The HANDBook OF LAB. ECON. 2485, 2508 (O. Ashenfelter \& D. Card eds., Elsevier 1999). In a 2008 study of the 250 largest companies included in the S\&P 500 Index, Frederick W. Cook \& Co. found no instances of discounted options; Cook's later studies omit the category of discounted options, pointing to their demise. The 2008 Top 250: Long-Term Incentive Grant Practices for Executives, FrederIC W. COOK \& Co., INC. 6 (2008), http://www.fwcook.com/content/Documents/Publications/2008_Top_250.pdf [https://perma.cc/5W6D-FVVF]. For later years, see also The 2009 Top 250: Long-Term Incentive Grant Practices for Executives, FREDERIC W. COOK \& Co., INC. (2009), http://www.fwcook.com/content/Documents/Publications/ 2009_Top-250-Report.pdf [https://perma.cc/UBC8-R3BR].

94 See supra Section II.C.1. See also the more recent development in Sutardja v. United States, 109 Fed. Cl. 358, 369 (2013), in which the court held that discounted stock options are a type of deferred compensation to which 409A applies. 
comprehensively covers the gamut of possible components of equity compensation.

\section{B. Evidence on the Decline of Options Grants as Compensation}

While the inclusion of both stock and options in executive compensation suites attempts to link executive interests with those of shareholders, the two function very differently in terms of incentives and risks. ${ }^{95}$ As described in Section II, Congress and federal regulators interminably legislate against the use of stock options. This Section describes how the equity composition of executive compensation packages has changed over the past decade in favor of stock compensation.

\section{Aggregate Increase in Stock and Decrease in Option Compensation}

Over the last ten years, there has been a significant reduction in option compensation and a sharp increase in stock compensation in executive pay packages. The following tables compare the aggregate contribution of stock options and stock to total senior executive pay at public companies for which executive pay data is available between 2006 and $2014 .{ }^{96}$ Figure 1 and Table 1 both track the changes in option compensation, stock compensation, and total equity compensation as percentages of total compensation for the years between 2006 and 2014. Figure 1 visually depicts the trend, while Table 1 numerically describes both the absolute changes in equity compensation as well as the rate of change for each component of equity pay.

95 See infra Section IV.

96 As discussed earlier in this Section, the analysis is limited to the group of companies listed on S\&P's Compustat database and by the inaccurate basis for comparison for the years prior to 2006. 


\section{FIGURE 1}

\section{Overall Equity Pay Composition of Executive Compensation Packages}

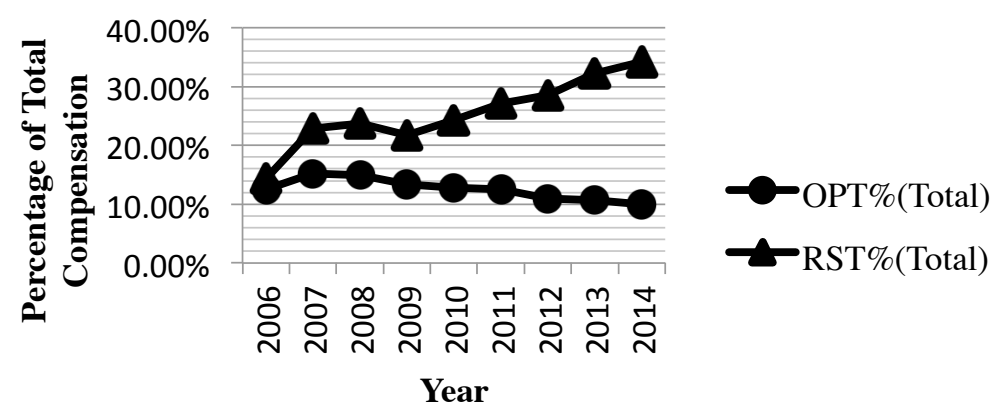

TABLE 1

\begin{tabular}{|l|c|c|c|c|c|c|c|c|c|}
\hline & $\mathbf{2 0 0 6}$ & $\mathbf{2 0 0 7}$ & $\mathbf{2 0 0 8}$ & $\mathbf{2 0 0 9}$ & $\mathbf{2 0 1 0}$ & $\mathbf{2 0 1 1}$ & $\mathbf{2 0 1 2}$ & $\mathbf{2 0 1 3}$ & $\mathbf{2 0 1 4}$ \\
\hline Option & $12.57 \%$ & $15.24 \%$ & $14.90 \%$ & $13.31 \%$ & $12.79 \%$ & $12.47 \%$ & $10.96 \%$ & $10.71 \%$ & $9.98 \%$ \\
\hline Change & $14.38 \%$ & $22.80 \%$ & $23.64 \%$ & $21.80 \%$ & $24.27 \%$ & $27.10 \%$ & $28.56 \%$ & $32.18 \%$ & $34.24 \%$ \\
\hline Stock & $26.95 \%$ & $38.04 \%$ & $38.54 \%$ & $35.11 \%$ & $37.06 \%$ & $39.57 \%$ & $39.52 \%$ & $42.89 \%$ & $44.22 \%$ \\
\hline Change & & $8.42 \%$ & $0.84 \%$ & $-1.84 \%$ & $2.47 \%$ & $2.83 \%$ & $1.46 \%$ & $3.62 \%$ & $2.06 \%$ \\
\hline $\begin{array}{l}\text { Total } \\
\text { Change }\end{array}$ & $11.09 \%$ & $0.50 \%$ & $-3.43 \%$ & $1.95 \%$ & $2.51 \%$ & $-0.05 \%$ & $3.37 \%$ & $1.33 \%$ \\
\hline $\begin{array}{l}\text { Probability } \\
\text { of } \\
\text { Statistical }\end{array}$ & $2.79 \%$ & $0 \%$ & $0 \%$ & $0 \%$ & $0 \%$ & $0 \%$ & $0 \%$ & $0 \%$ & $0 \%$ \\
\hline
\end{tabular}

97 This row is the result of a paired t-test comparing the two means using Stata's t-test command. The results show that while the stocks and options given out were relatively similar in 2006, only one year later the averages diverged in a statistically meaningful way. Although a more nuanced statistical analysis (e.g., a multivariable analysis) could be performed, such an analysis would require significant controls to address problems such as the omitted variable bias. Because the purpose of this Note is merely to document the changes in equity compensation, rather than explain its determinants, this t-test is the appropriate analysis. 
As Figure 1 depicts, options and stock accounted for virtually the same percentage of the aggregate value of senior executive pay in 2006-just before the implementation of the change in the tax and accounting rules. ${ }^{98}$ Options accounted for $12.5 \%$, and stock accounted for $14 \%{ }^{99}$ David Walker's pre-2008 analysis on the make-up of pay packages of senior executives at S\&P 500 companies shows that prior to 2002, stock had never accounted for more than $15 \%$ of total ex ante compensation. ${ }^{100}$ In 2007 , however, immediately after the tax and accounting rules came into effect, stock jumped to almost $23 \%$ of total compensation, an increase of eight percentage points. ${ }^{101}$ From then on, the contribution of stock pay continued to rise, reaching over $34 \%$ of total compensation and almost $80 \%$ of equity compensation in 2014. ${ }^{102}$ Option pay, on the other hand, steadily declined since 2007 , reaching just below $10 \%$ of total compensation in 2014, or approximately $23 \%$ of equity compensation. ${ }^{103}$ By 2014, the difference between stock and option compensation had widened to over $24 \%$ of total compensation. ${ }^{104}$

Previous scholarship predicted that overall equity pay would continue to rise after the recession of 2008. ${ }^{105}$ These results confirm that view. In 2008, total equity compensation accounted for almost $39 \%$ of the value of the executive compensation package. ${ }^{106}$ Total equity compensation steadily increased to over $44 \%$ in 2014, far overtaking the pre-2008 levels. ${ }^{107}$ As Table 1 shows, stock compensation generally tracks total equity compensation. Thus, the overall rise in

98 See supra Figure 1.

99 See supra Table 1.

100 See Walker, supra note 86, at 633.

101 See supra Table 1.

$102 I d$. 2009 is the exception to this trend, when total equity compensation also dipped.

103 Id.

104 Id.

105 See, e.g., Walker, supra note 61, at 1509.

106 See supra Table 1.

107 Id. 
the equity proportion of total compensation can be largely attributed to the increase in stock compensation. The evidence above suggests that firms across the United States are embracing two themes: the first is pay-for-performance codified in Section 953 of Dodd-Frank, while the second is the preference for conservative behavior. Preliminary studies on 2015 suggest that the trend continues. ${ }^{108}$

\section{Effects of CEO's Age on Equity Composition}

Yet, the increase in stock compensation could simply be a function of executives growing more risk-averse as they age. Prior academic scholarship, as well as formal psychological and behavioral economic studies, suggests that age affects the risk tolerance of individuals. ${ }^{109}$ One possibility is that

\footnotetext{
108 Eleanor Bloxham, Years of CEO Stock Incentives Are Causing Economic Volatility Today, ForTUNE (Feb. 1, 2016), http://fortune.com/2016/02/01/ceo-pay-stock-economic-volatility/ [https://perma.cc/9QRR-Y88K].

109 See, e.g., Jarkko Peltomäki, Steve Swidler, \& Sami Vähämaa, Age, Gender, and Risk-Taking: Evidence from the S\&P 1500 Executives and Firm Riskiness (Dec. 15, 2016) (unpublished study), https://papers.ssrn.com/sol3/papers.cfm?abstract_id=2547516. The authors examined whether the age of a firm's top executives is reflected in firmlevel riskiness. Using data on CEOs and CFOs at the S\&P 1500 firms, they found that executives grow more risk-averse with age and may constrain excessive risk-taking by their firms. See also Gurdip S. Bakshi \& Zhiwu Chen, Baby Boom, Population Aging, and Capital Markets, J. Bus., Apr. 1994, at 176 (finding a negative relationship between age and risky investment behavior); Anika K. Josef et al., Stability and Change in RiskTaking Propensity Across the Adult Lifespan, 111 J. PERS. \& Soc. PsYchol. 430, 436 (Sept. 2016) (showing the propensity to take risks particularly declines after 30 in young adults and after 65 for older adults); Julia Deakin et al., Risk Taking During Decision-Making in Normal Volunteers: Changes with Age, 10 J. InT'L Neuropsychological Soc. 590, 593 (2004) (finding older adults less willing to take risks); Don Bellante \& Carole A. Green, Relative Risk Aversion Among the Elderly, 13 REv. Fin. Econ. 269, 277 (2004) (finding older adults picked more risk-averse options through an analysis of investment portfolio allocations); Victor H. Vroom \& Bernd Pahl, Relationship Between Age and Risk Taking Among Managers, 55 J. APPlied Psychology 399, 403 (1971) (finding a significant negative relationship between age and both risk-taking and the value placed upon risk). But see John E. Grable, Financial Risk Tolerance and Additional
} 
older executives bargain for renewed compensation packages that reflect a lower tolerance for risk, choosing stock compensation over option compensation. The evidence contained in Figure 2, however, suggests that the more likely answer is attributable to a general trend in favor of incentivizing conservative behavior. ${ }^{110}$

Figure 2 describes the percentage of options and stock of total compensation for executives under age forty-five and executives over age sixty-four: ${ }^{111}$

\section{FIGURE 2}

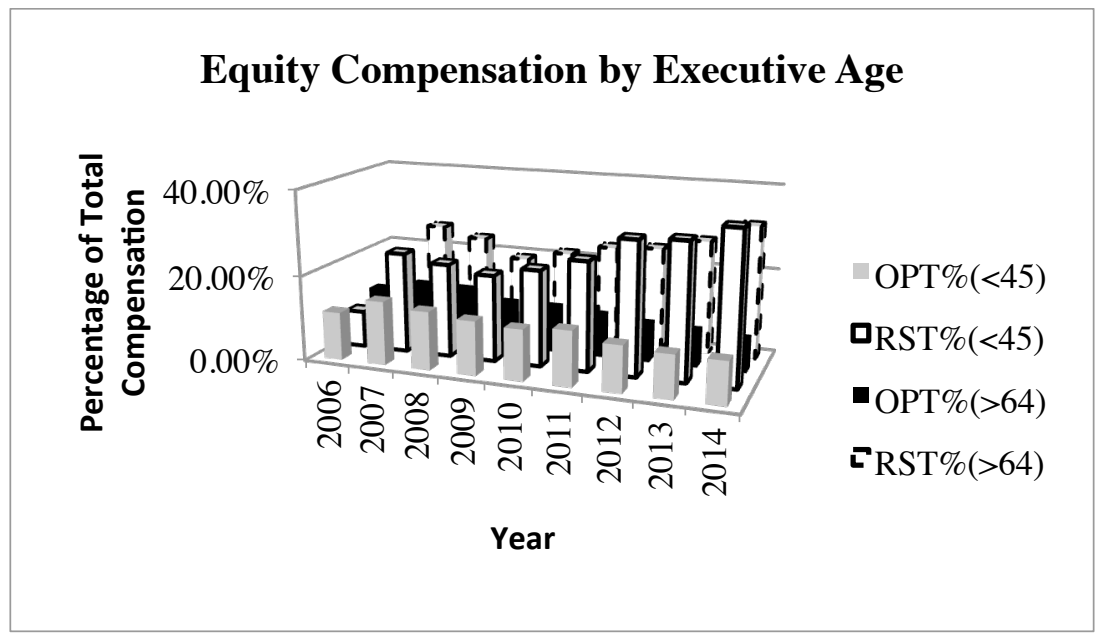

Factors That Affect Risk Taking in Everyday Money Matters, 14 J. Bus. \& PSYCHOL. 625 (2000) (finding a positive relationship between age and risk taking).

110 This analysis does not mean to suggest that the findings are statistically significant when controlling for factors like industry or tenure. Rather, this Section provides the evidence as descriptive difference.

111 The average age for a CEO in 2015 was fifty-five. Executives aged forty-five and younger represent the bottom quartile, while those aged sixty-four and older represent the top quartile. Interestingly, the evidence shows that in 2006 more than sixteen times as many executives sixty-four and older (2548) were recorded than those forty-five and younger (154). By 2014, however, the numbers had evened out: 602 executives sixty-four and older, and 874 executives forty-five and younger. 
TABLE 2

\begin{tabular}{|c|c|c|c|c|c|c|c|c|c|}
\hline & \multicolumn{9}{|c|}{ Executive Younger than 45} \\
\hline & 2006 & 2007 & 2008 & 2009 & 2010 & 2011 & 2012 & 2013 & 2014 \\
\hline Stock & $8.49 \%$ & $23.58 \%$ & $21.91 \%$ & $20.29 \%$ & $22.49 \%$ & $25.55 \%$ & $31.26 \%$ & $31.90 \%$ & $35.49 \%$ \\
\hline Option & $11.25 \%$ & $24.94 \%$ & $13.69 \%$ & $12.67 \%$ & $11.97 \%$ & $12.90 \%$ & $10.87 \%$ & $10.11 \%$ & $9.97 \%$ \\
\hline $\begin{array}{l}\text { Probability } \\
\text { of } \\
\text { Statistical } \\
\text { Similarity } \\
112\end{array}$ & $0 \%$ & $5.24 \%$ & $0.13 \%$ & $0 \%$ & $0 \%$ & $0 \%$ & $0 \%$ & $0 \%$ & $0 \%$ \\
\hline & \multicolumn{9}{|c|}{ Executive Older than 64} \\
\hline & 2006 & 2007 & 2008 & 2009 & 2010 & 2011 & 2012 & 2013 & 2014 \\
\hline Stock & $15.72 \%$ & $25.59 \%$ & $23.40 \%$ & $19.09 \%$ & $21.27 \%$ & $23.63 \%$ & $24.29 \%$ & $26.93 \%$ & $31.36 \%$ \\
\hline Option & $11.29 \%$ & $13.34 \%$ & $13.16 \%$ & $10.81 \%$ & $10.80 \%$ & $10.00 \%$ & $9.02 \%$ & $8.56 \%$ & $7.74 \%$ \\
\hline $\begin{array}{l}\text { Probability } \\
\text { of } \\
\text { Statistical } \\
\text { Similarity } \\
113\end{array}$ & $0 \%$ & $0 \%$ & $0 \%$ & $0 \%$ & $0 \%$ & $0 \%$ & $0 \%$ & $0 \%$ & $0 \%$ \\
\hline
\end{tabular}

The evidence demonstrates that the pay suites of older executives generally contain a lower percentage overall of equity compensation than those of younger executives, thus affirming either that older executives are indeed more riskaverse than younger executives at the time of hire, or that they have kept essentially the same executive compensation package since the start of their tenure. The difference in option compensation between older and younger executives, however, has generally remained within two percentage points. ${ }^{114}$ Hence, it is difficult to conclude that the lower tolerance for risk attributed to older executives is responsible for the general decline in the use of option compensation. Were that the case, the increase in stock compensation of younger executives would not have so drastically outpaced the increase in that of older executives.

112 For explanation, see supra note 97.

113 Id.

114 See supra Table 2. 2011 is an outlier, when executives younger than forty-five received almost thirteen percent of their total compensation in stock options, while executives older than sixty-four received ten percent in stock options. 
Figure 2 and Table 2 show that senior executive pay composition of younger executives tracks the general trend seen in Figure 1 far more closely than does that of older executives. Thus, executive turnover seems to be the stronger determinant of senior executive compensation, with compensation packages determined by the general trends at the time of hire. ${ }^{115}$ While both older and younger executives may be recruited for open positions, executives who are under forty-five in 2014, for example, are far less likely to have been in the same position five years earlier. Consider the executive who is hired in 2004, and who bargained for the receipt of one million options each year. Her compensation package in 2014 will look drastically different from that of the new CEO hired in the wake of Dodd-Frank, with the company more likely to structure compensation packages to induce senior executives to focus on long-term effects. Thus, the ages in 2014 of the 2004 hiree and the 2014 hiree are likely statistically insignificant, although this analysis is beyond the scope of this Note. Rather, younger executives are more likely than new hires to have been among the company's five highest paid employees several years earlier. In sum, the pay packages of younger executives are more likely to reflect the prevailing trends in executive compensation than those of older executives.

\section{Trends for CEOs}

Many of the headlines and studies decrying "excessive" executive compensation have focused on the pay of CEOs. ${ }^{116}$

115 See supra note 111. There has been a drastic decrease in the number of executives aged sixty-four and older, and a sharp increase in those aged forty-five and younger between 2006 and 2014. This further suggests that the result is due to executive turnover rather than tenured executives growing more risk-averse with age.

116 See, e.g., Joann S. Lublin, How Much the Best-Performing and Worst-Performing CEOs Got Paid, WALL ST. J. (June 25, 2015), http://www.wsj.com/articles/how-much-the-best-and-worst-ceos-got-paid1435104565. The article called out Viacom Inc.'s Philippe Dauman and General Electric Co.'s Jeff Immelt as two of the ten best-paid CEOs and as receiving higher compensation in 2015 despite the total shareholder value 
Yet the legislation and tax restructuring discussed in Part II should affect the composition of all senior executive compensation packages equally: the SEC did not single out CEOs for enhanced disclosure. The evidence in Figure 3, however, paints a different story.

Figure 3 compares the percentages of stock and options in overall senior executive compensation with those of CEOs. ${ }^{117}$

at each company falling that year. Id.; see also Michael C. Jensen \& Kevin J. Murphy, CEO Incentives-It's Not How Much You Pay, But How, HaRv. BUS. REV. (1990), https://hbr.org/1990/05/ceo-incentives-its-not-how-muchyou-pay-but-how [https://perma.cc/3PD7-K482](providing a review of U.S. CEO compensation from 1969 to 1983 and revealing that CEO pay is hardly keyed to the performance of the corporations they run). See also Walker, supra note 86, at 613 for a study of the make-up of CEO compensation packages between 1992 and 2006 .

117 Interestingly, the data include different numbers of CEOs than CFOs. In 2006, 1333 CEOs, but only 770 CFOs, were included. In 2013, there were about 1000 more CEOs reported than CFOs. However, by 2014, the gap had narrowed: 1773 CEOs were included, compared to 1771 CFOs. Interestingly, the SEC disclosure rules mandate that each company must report the executive compensation package make-up of the $\mathrm{CEO}, \mathrm{CFO}$, and the three next-highest-paid executives; consequently, after 2006, the number of CEOs and CFOs reported should be identical. Executive Compensation and Related Person Disclosure, 71 Fed. Reg. 53,158, 53,241 (Sept. 8, 2006) (to be codified at 17 C.F.R. pts. 228, 229, 232, 239, 240, 245, 249, 274). Resolving this discrepancy is beyond the scope of this Note. 
FIGURE 3

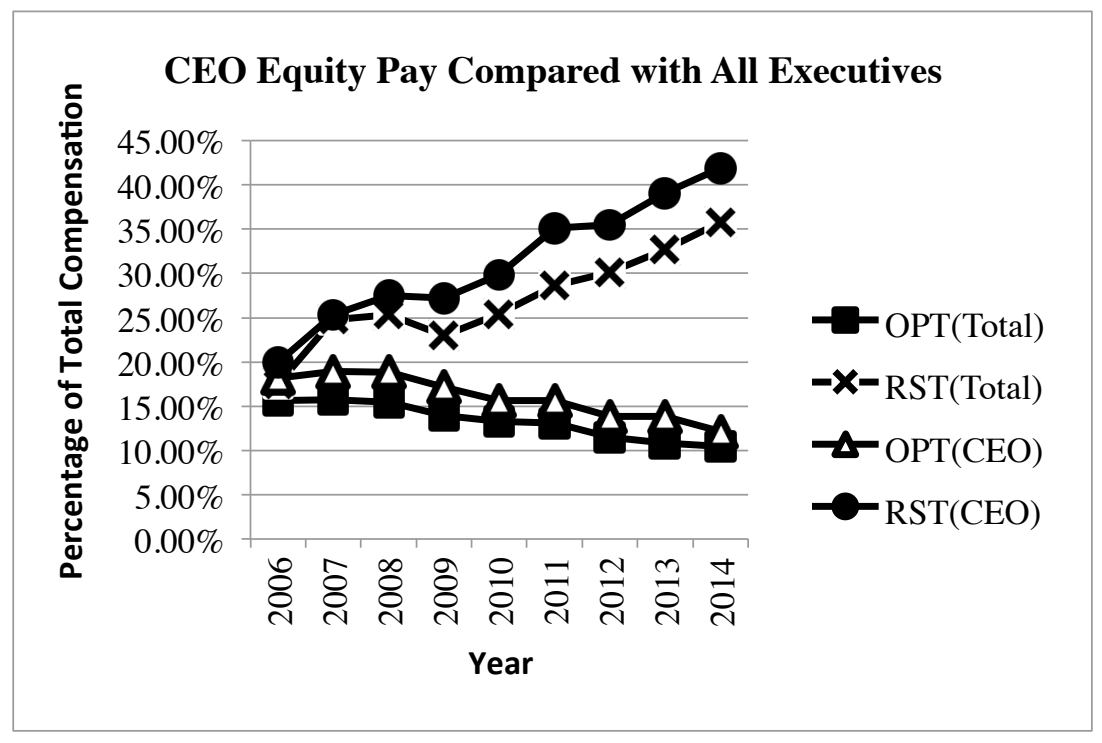

Figure 3 demonstrates that while both components of CEO equity compensation outpaced equity compensation for all executives, the components of CEO equity compensation grew at different rates. The difference between the option composition of CEO compensation and overall compensation narrowed over time. In 2006, options comprised $15 \%$ of CEOs' packages compared to $12.5 \%$ overall. The most recent data from 2014 show that while CEOs are still granted more options than other executives, the difference in option composition between CEOs and other executives is currently only $1.5 \%$. The difference between the stock compensation of CEOs and that of executives overall, however, has widened from a gap of $2 \%$ in 2006 to almost 6\% in 2014. Stocks currently make up about $78 \%$ of CEOs' equity pay and almost $40 \%$ of the total compensation package.

It is unsurprising that CEOs receive a greater composition of their compensation in the form of equity pay for two reasons. The first is that the CEO is the public face of the company and is held responsible for its performance by 
external shareholders. ${ }^{118}$ Thus, it is logical to tie a greater percentage of a CEO's pay to the performance of the company. The second is that equity-based pay may give CEOs an incentive to take on risk. If stock returns dip, for example, CEOs will begin to worry about their own portfolios and consider an acquisition or share buy-back to increase the value of the shares. Other senior executives, including CFOs, are not granted the same decision-making authority as CEOs, so CFOs' base salaries have greater weight in their compensation mix. ${ }^{119}$ Figure 3 demonstrates that CEOs received over 7\% more equity compensation in 2014 than other senior executives.

Thus, the shift to stock-based compensation has more quickly and drastically affected CEO pay compared to that of other senior executives. Additionally, this shift toward stockbased pay has had more of an impact on CEO compensation than did the shift away from option-based pay. That the difference between stock and option compensation has fluctuated over the nine-year period shows that companies, neither mandated by SEC disclosure regulations nor incentivized by tax rules, have taken it upon themselves to adjust the pay of CEOs more sharply than that of other senior executives.

118 A.G. Lafley, What Only the CEO Can Do, Harv. Bus. REv., May 2009, https://hbr.org/2009/05/what-only-the-ceo-can-do [https://perma.cc/ 7LTR-W4M6].

119 The composition of CFO equity compensation closely tracks that of overall equity compensation. After 2007, the difference between CFO equity compensation and overall equity compensation barely wavered above $1 \%$ for both stock and option compensation. This result is not unexpected: SEC disclosure rules and tax rules have vacillated between including CFOs among the most highly compensated executives, and mandating the disclosure of $\mathrm{CFO}$ compensation regardless of whether they are the most highly compensated executives. Executive Compensation and Related Person Disclosure, 71 Fed. Reg. at 53,241; see supra note 63. Data is author's own. 


\section{Firm Size}

A number of authors have used firm size to evaluate executive compensation. ${ }^{120}$ As the S\&P 500 index includes the companies that dominate the U.S. stock market in terms of market capitalization, it is generally used as a benchmark for academic studies. ${ }^{121}$ Furthermore, large firms-including Aetna, Oracle, and CBS-have become household names and have received the brunt of the blame for runaway executive compensation. ${ }^{122}$

Given the implications of firm size in prior studies, perhaps the composition of executive compensation should vary accordingly -indicated by the S\&P 500, MidCap 400, and SmallCap 600 indices. Below in Figure 4 and Table 3, the senior executive pay packages of S\&P 500 firms are

120 See, e.g., Xavier Gabaix \& Augustin Landier, Why Has CEO Pay Increased So Much?, 123 Q. J. Econ. 20 (forthcoming 2008) (finding a positive correlation between CEO pay and market capitalization in market equilibrium); Marianne Bertand \& Kevin F. Hallock, The Gender Gap in Top Corporate Jobs, 55 InDUs. LAB. REL. REV. 3, 7 (2001) (finding that the gender pay gap among the highest paid executives is positively related to firm size); Peter F. Kostiuk, Firm Size and Executive Compensation, J. Hum. RESOURCES 90 (1990) (finding that there is significant variability in the level of compensation between firms of the same size); Mary Ellen Carter \& Luann J. Lynch, An Examination of Executive Stock Option Repricing, 61 J. FIN. ECON. 207, 219 (2001) (finding that stock option resetting is more common in smaller firms).

121 There is over $\$ 7.8$ trillion benchmarked to the index, capturing approximately eighty percent of market capitalization. S\&P 500, S\&P Dow JONES INDICES, http://us.spindices.com/indices/equity/sp-500 [https://perma.cc/VYG3-P8GM].

122 See, e.g., Theo Francis \& Joann S. Lublin, CEO Pay Rises Moderately; a Few Reap Huge Rewards, WALL ST. J. (May 27, 2014), http://www.wsj.com/articles/ceo-pay-rises-moderately-a-few-reap-hugerewards-1401235102?tesla=y; David Gelles, For the Highest-Paid C.E.O.s, the Party Goes On, N.Y. Times (May 16, 2015), http://www.nytimes.com/2015/05/17/business/for-the-highest-paid-ceosthe-party-goes-on.html?_r=0 [https://perma.cc/4EP9-KNFM]; Paul Hodgson, Why Oracle Shareholders Keep Rejecting The Company's Executive Pay, ForTunE (Nov. 25, 2015), http://fortune.com/2015/11/25/oracle-shareholders-executive-pay/ [https://perma.cc/4JDD-RJBT]. 
compared with those of MidCap 400 firms and SmallCap 600 firms to identify whether firm size dictates the composition of executive pay. ${ }^{123}$

FIGURE 4

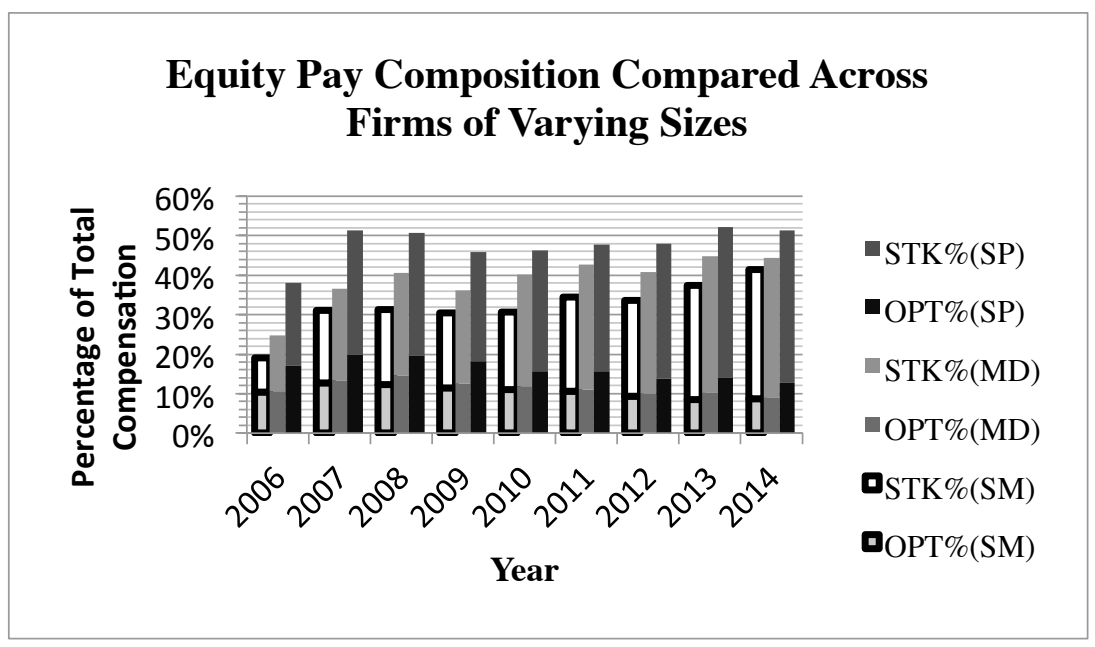

TABLE $3^{124}$

\begin{tabular}{|l|l|l|l|l|l|l|l|l|l|}
\hline & $\mathbf{2 0 0 6}$ & $\mathbf{2 0 0 7}$ & $\mathbf{2 0 0 8}$ & $\mathbf{2 0 0 9}$ & $\mathbf{2 0 1 0}$ & $\mathbf{2 0 1 1}$ & $\mathbf{2 0 1 2}$ & $\mathbf{2 0 1 3}$ & $\mathbf{2 0 1 4}$ \\
\hline Ratio(SM) & 0.82 & 1.44 & 1.55 & 1.68 & 1.79 & 2.25 & 2.59 & 3.38 & 3.74 \\
\hline Ratio(MD) & 1.32 & 1.74 & 1.75 & 1.91 & 2.35 & 2.90 & 3.08 & 3.43 & 4.03 \\
\hline Ratio(SP) & 1.22 & 1.58 & 1.57 & 1.53 & 1.97 & 2.04 & 2.49 & 2.72 & 3.07 \\
\hline
\end{tabular}

The total equity composition of senior executive pay at S\&P 500 companies is markedly higher than that of either

123 As with the data on executive age, this analysis does not mean to suggest that the findings are as statistically significant when controlling for factors like industry. Rather, this Section provides the evidence as descriptive difference.

124 This table describes the ratio between the percentages of stock and option grants for SmallCap, MidCap, and S\&P 500 companies found through the Compustat database. 
MidCap or SmallCap firms: by 2014, executives at S\&P companies received $54 \%$ of their compensation in equity pay, compared to $44 \%$ at MidCap firms and $41 \%$ at SmallCap firms. Figure 4 shows that in the case of SmallCap firms, equity pay only made up about $19 \%$ of executive compensation in 2006 , but jumped to $32 \%$ in 2007 . While the MidCap and S\&P 500 firms show a similar increase in 2007, equity has been the most substantial component of executive compensation at S\&P 500 firms for the entirety of the study. These results demonstrate that after the tax and disclosure changes in 2006, the structure of executive compensation changed universally.

Comparing the increase in total equity compensation to the weight of the equity components reveals interesting differences. First, although the percentage of total equity compensation increased overall, the rate of growth is far faster at SmallCap and MidCap firms than at S\&P 500 companies. There is an approximate $20 \%$ increase for the smaller firms, and a 10\% increase for the larger firms. Second, the weight of stock options overall decreases after 2007, but far more rapidly for S\&P 500 firms (over 7\%) than for either of the two smaller firm groups (about 4\% each). Finally, Table 3 shows the ratio between stock and option compensation for each of the firm group indices. Similarly, by 2014 , there is a significant departure between the ratios of SmallCap and MidCap firms and that of S\&P 500 firms: the percentage of stock compensation is thus far higher than that of option compensation at the smaller firms. In 2006, however, the ratios not only were smaller overall, but also much closer in size across the three firm indices. Thus, the results in Figure 4 and Table 3 reveal that while the total equity compensation and component weights are significantly different for firms across the S\&P 500, MidCap 400, and SmallCap 600 indices, the change in growth between the component parts remains relatively similar across the board. 


\section{IMPLICATIONS FOR POLICYMAKERS}

The composition of executive compensation suites drew much scrutiny in the last decade from commentators and lawmakers. ${ }^{125}$ The evidence presented in this Note shows that since 2006, senior executives are increasingly likely to be rewarded with stock compensation rather than option compensation, with a particularly dramatic surge following the financial crisis and corresponding congressional action. ${ }^{126}$ The data also demonstrate that this trend discriminates by neither firm size nor executive age.

This Section discusses two implications of these findings for current debates on executive compensation at public companies. First, executives compensated in stock options tend to engage in riskier behavior, since option-based compensation allows them to benefit from the upside of a bold decision without suffering the consequences of the downside. Consequently, executives may generate benefits at the expense of the shareholder. Given the drastic decrease in option compensation, we expect to see far more conservative behavior at public companies-and as a consequence, an increase in shareholder activism to counter this trend.

Second, the shift from option-based compensation to stock-based compensation has important tax implications. While the tax code favors option-based compensation, ${ }^{127}$ many senior executives currently receive the majority of their equity compensation in the form of company stock. Attempts to fit stock-based compensation into an optionbased tax code have created perverse results, harming firms and shareholders alike. ${ }^{128}$

\section{A. Risk-Taking for Executives}

One purpose of executive compensation plans is to align the incentives of executives with those of shareholders. A

\footnotetext{
125 See supra notes 3 and 4.

126 For a discussion of this evidence, see supra Section III.B.

127 See supra Section II.C.1.

128 See infra Section IV.A and Section IV.B.
} 
great challenge is to counteract the executive's natural risk aversion and self-advancement. ${ }^{129}$ Stock options are generally presented as the solution because they have an asymmetric payoff: a "virtually unlimited" upside if stock prices rise, and only minimal consequence if the executive's strategy fails to increase stock prices, since the executive does not bear any additional loss other than the loss of options. ${ }^{130}$ The underpinning is that the objective option value increases with stock price volatility. Indeed, Bebchuk et al. argue that efficient pay contracts should include a mix of stock and options that best balances incentives and risk. ${ }^{131}$ The first subsection more deeply discusses the problems that suboptimal risk-taking cause, while the second considers shareholder activism as a possible consequence to suboptimal risk-taking.

\section{Risk-Taking: The Issue}

There have long been concerns that options may provide harmful impetuses that drive executives to immoderately take risks and decrease dividends to shareholders. Richard Posner declared that an overreliance on stock options incentivized CEOs to create stock price bubbles and "hope for the best." 132 Accordingly, and especially in the aftermath of the accounting scandals of the early 2000's and the financial crisis of 2008, legislators and regulators became determined to disfavor stock options.

Yet, suboptimal risk-taking can take the form of either excessive risk-taking or underinvestment-both of which

129 There is a wealth of academic literature that rests on the assumption of global risk aversion by executives. See, e.g., Bebchuk \& Fried, supra note 7; Bebchuk et al., supra note 9; Bhagat \& Romano, supra note 5; Jackson, supra note 9; David I. Walker, The Law and Economics of Executive Compensation: Theory and Evidence, in RESEARCH HANDBOOK ON THE ECONOMics of Corporate LAw 232 (Claire A. Hill \& Brett H. McDonnell eds., 2011).

130 Lee Harris, CEO Retention, 65 FL. L. REV. 1753, 1763 (2013).

131 Bebchuk et al., supra note 9, at 756-57.

132 Richard A. Posner, A Failure of Capitalism: The Crisis of '08 AND the DESCEnT INTO DEPRESSION (2009). 
may lead to reductions in aggregate welfare. In the absence of devices like stock options, there is good reason to believe that managers will be overly conservative. ${ }^{133}$ Without the incentives tied to option compensation, executives are less likely to take risks for two reasons. First, executives make significant investments in the firm, which they are unlikely to recoup if the company fails. Second, failure can impose significant losses on executives in terms of reputational capital. Thus, because executives reap high salaries and benefits from their positions, they likely will not make waves and risk their jobs for a riskier project that their shareholders may prefer. ${ }^{134}$ Presumably, executives need to be prodded to take steps contrary to their own priorities. Indeed, executives have every incentive to reduce their risk exposure even as equity pay enhances options for them, by hedging, backdating option grants, and similar schemes. ${ }^{135}$

The tension between mitigating recklessness and avoiding excessive conservatism is clear. Forcing executives to hold stock rather than options mitigates earnings manipulation and "bet-the-company" risk taking, but also increases executive risk-aversion and conservatism. ${ }^{136}$ Riskaverse executives will generally prefer shorter-term, more incremental projects that are relatively safe, over longerterm research and development intensive projects, which are more risky. ${ }^{137}$ Shareholders may wish to encourage

133 Walker's article demonstrates that as risk aversion increases, the optimal executive pay design shifts in the direction of stock, since a highly risk-averse option recipient will greatly discount options that have a more remote payoff prospect. See Walker, supra note 86, at 622 .

134 David I. Walker, The Challenge of Improving the Long-Term Focus of Executive Pay, 51 B.C.L. REV. 435, 446 (2010).

135 Id. at 442 (at the extreme, hedging transactions can completely eliminate firm-specific risk). See also supra Section II.C.3 for a discussion on backdating option grants.

136 Walker, supra note 14 , at 447.

137 As one example, consider a large investment in research and development by a pharmaceutical company. The cost of bringing a new drug to market is very sensitive to changes in science and technology, shifts in the types of drugs under development, and changes in the regulatory market. Consequently, it is impossible to predict with certainty 
executives to be more aggressive and engage in beneficial risk-taking that matches shareholders' preferences; risky projects may be more valuable than safe projects for shareholders. The concern is that this new balance of equity compensation could shift too far in the direction of conservatism, halting the long-term performance of U.S. companies.

\section{Increased Shareholder Activism as a Consequence of Suboptimal Risk-Taking}

This suboptimal risk-taking on the part of CEOs brings the firm back to the original agency problem that stockoption compensation was intended to fix. The natural aversion on the part of the manager, who stands to lose invested wealth, firm-specific human capital, and the benefits associated with control, lies counter to shareholders' interests. Because risk and reward are positively correlated, a higher NPV project will likely be the riskier one-and, generally speaking, shareholders will prefer that project, even though managers may prefer the less risky project. Thus, unlike managers who are risk-averse, shareholders come to the table with the financial incentive to maximize firm value. Shareholder activism shifts the balance by allowing shareholders to vote out the CEO if her underperformance limits the firm. Thus, a change in pay

the cost of bringing a new drug to market from estimated costs for drugs whose development began more than a decade ago. Additionally, the full cost of bringing a new drug to market requires huge outlays of cash, which ties up cash flows and may prevent the company from paying off its debt. This could lead to a sharp decrease in stock price, initially-until (or if) the drug generates massive returns at some future date. Between 2010-2014, 143 new products were launched with projected lifetime revenues of $\$ 955$ billion, equaling returns of $5.5 \%$. At the same time, however, for every $\$ 5$ gained through asset launch, $\$ 2$ are lost through failure. DELOITTE CTR. for Health Solutions, Measuring the Return from Pharmaceutical INNOVATION 2014: TURNING A CORNER? 3-4 (2014), http://www2.deloitte.com/content/dam/Deloitte/uk/Documents/life-scienceshealth-care/measuring-the-return-from-pharmaceutical-innovation2014.pdf [https://perma.cc/GSF8-655T]. 
structures can be viewed as a justification for further shareholder reform.

The past decade shows that shareholder activism has been steadily increasing, both in terms of monitoring managers and effectuating decisions. ${ }^{138}$ Since the end of $2009,15 \%$ of companies on the S\&P 500 index have faced an activist campaign, ${ }^{139}$ and activists have not discriminated in terms of firm size, age, or prestige. Indeed, recently, activists have targeted several of the largest firms by market capitalization, ${ }^{140}$ the oldest firm on the NYSE, ${ }^{141}$ and today's technology and consumer giant. ${ }^{142}$ While out of the approximately 8000 hedge funds, only 71 (less than 1\%) are activist, the activist funds account $4 \%$ of the $\$ 120$ billion under management in 2014 and raised one-fifth of all cash

138 Andrew C. W. Lund \& Gregg D. Polsky, The Diminishing Return of Incentive Pay in Executive Compensation Contracts, 87 NoTRE DAME L. REV. 677, 693 (2012).

139 Activist Funds: An Investor Calls, The Economist (Feb. 7, 2015), http://www.economist.com/news/briefing/21642175-sometimes-illmannered-speculative-and-wrong-activists-are-rampant-they-will-changeamerican [https://perma.cc/SZ98-EN42] (defining "campaign" as "an effort to change a firm's strategy, acquire board seats or remove managers.").

140 In 2013, Bill Ackman of Pershing Square began a campaign against Procter \& Gamble that resulted in its CEO's replacement in 2015. See Chris Isidore, Ackman Wins, P\&G Dumps CEO, CNN (May 24, 2013), http://money.cnn.com/2013/05/24/news/companies/pg-ceo-ackman/ [https://perma.cc/Y3B8-ZUFL].

141 In 2014, Daniel Loeb of Third Point along with Marcato Capital Management launched a hostile and public bid for Sotheby's that resulted in a win of three board seats for the fund. See Truce! Dan Loeb's Third Point Gets 3 Board Seats, But Sotheby's CEO Bill Ruprecht Stays on Board, FORBES (May 5, 2014), http://www.forbes.com/sites/ afontevecchia/2014/05/05/truce-dan-loebs-third-point-gets-3-board-seatsbut-sothebys-ceo-bill-ruprecht-stays-on-board/\#b8c55dc1501e [https://perma.cc/6XQN-HTMJ].

142 In 2013, the famed corporate raider Carl Icahn took a position in Apple Inc. to seek a larger dividend payout to shareholders. See Adam Satariano, Carl Icahn Pushes for Bigger Investor Payout from Apple, BLOOMBERG (Aug. 14, 2013), https://www.bloomberg.com/news/articles /2013-08-14/carl-icahn-pushes-for-bigger-investor-payout-from-apple [https://perma.cc/2D9Z-3H5N]. 
flows. ${ }^{143}$ In the past five years, one in every seven companies on the S\&P 500 has been on the receiving end of an attack, but one in two has had a large activist fund in its share register. ${ }^{144}$ Clearly, hedge funds are getting more involved in shareholder activism and hold the potential to encourage change in control when they see a firm underperforming.

As Marcel Kahan and Edward Rock posit, "if a CEO makes mistakes (or perhaps just has back luck), both shareholders and directors will voice their criticism sooner and more strongly than in the days of yore, be it informally, [or] through ... a board-induced CEO resignation."145 Furthermore, a recent paper by Thomas Keusch predicted that companies targeted by activist investors will see higher CEO turnover, especially when the activist wins a board seat. $^{146}$ Before an activist engagement, CEO turnover at targeted firms tended to be similar to turnover at control group firms. Within two years post-engagement, however, targeted firms tended to see between $5-6 \%$ more turnover. ${ }^{147}$ Today, the average tenure of an S\&P 500 CEO has shrunk in the years after 1998 to a little more than six years, even while the S\&P 500 Index rose more than threefold. ${ }^{148}$ And perhaps equally as important as the victories that the shareholders have won are the battles that they have not had to fight-those where they can influence managerial decision-making without ousting the CEO.

143 Activist Funds: An Investor Calls, supra note 139.

144 Shareholder Activism: Capitalism's Unlikely Heroes, THE ECONOMIST (Feb. 7, 2015), http://www.economist.com/news/leaders /21642169-why-activist-investors-are-good-public-company-capitalismsunlikely-heroes [https://perma.cc/N9FT-VU3C].

145 Marcel Kahan \& Edward B. Rock, Embattled CEOs, 88 TEx. L. REV. 987, 1040 (2010).

146 Thomas Keusch, Shareholder Power and Managerial Incentives 12 (Mar. 2016) (unpublished working paper), http://papers.ssrn.com/sol3/ papers.cfm?abstract_id=2746135 [https://perma.cc/Y4BS-JFZL].

147 Id. at 21 .

148 Joann S. Lublin, CEO Tenure, Stock Gains Often Go Hand-inHand, WALL ST. J. (July 6, 2010, 12:01 AM), http://www.wsj.com/articles/SB100014240527487039000045753251726814 19254. 
Unlike other institutional investors who typically sell their shares when the portfolio company underperforms, hedge funds do not sell services to the class of companies they target. Consequently, they are independent actors in governance activism and are able to influence compensation and turnover decisions. Keusch's evidence suggests that "hedge fund activists monitor whether CEOs' actions are in line with shareholders' interests and are in part responsible for rebalancing incentives in portfolio companies." 149 Presenting a counterweight to the manager's natural and policy-driven risk aversion, activists are able to fill the governance void that afflicts today's public companies.

Thus, the evidence in this Note may justify a movement towards further shareholder reforms that seek to give shareholders a larger voice. In 2009, SEC Chairman Mary Schapiro remarked that one way that Wall Street must repair itself after the financial crisis is by "giving shareholders a greater say on who serves on corporate boards, and how company executives are paid."150 While steps have since been taken to grant shareholders greater power, ${ }^{151}$ the current model still fails to offer a "platform conducive to aggressive entrepreneurship,"152 and instead rewards risk aversion and institutional stability.

149 Keusch, supra note 146 , at 7.

150 Zachary A. Goldfarb, SEC to Examine Boards' Role in Financial Crisis, WAsh. Post (Feb. 20, 2009), http://www.washingtonpost.com/wpdyn/content/article/2009/02/19/AR2009021903172.html?sid=ST2009021903 215 [https://perma.cc/C8TC-5P2Y].

151 See, e.g., Dodd-Frank, supra note 65, at $\S \S 951$ (shareholder vote on executive compensation disclosures), 952 (independence of compensation committees) 953 and 955 (pay for performance and pay parity disclosures), 954 (clawbacks), 971 (proxy access), and 972 (mandating statement of reasons not to split the chairman-CEO position), among others.

152 William W. Bratton \& Michael L. Wachter, The Case Against Shareholder Empowerment, 158 U. PA. L. REV. 653, 655 (2010). 


\section{B. Tax Concerns}

After concluding that certain executive compensation practices are undesirable, Congress sought to use the tax code to discourage companies and their executives from engaging in such practices. ${ }^{153}$ The two examples discussed in this Note include the $\$ 1$ million deduction limitation, unless pay is tied to performance, ${ }^{154}$ and the nonqualified deferred compensation regulation. ${ }^{155}$ This Part will discuss the unintended effects of the option-based tax code provisions on both public companies and shareholders now that stock grants comprise the majority of equity compensation.

\section{Deferrals}

Compared with stock compensation, option compensation allows executives to defer taxation beyond vesting. ${ }^{156}$ It also allows them to control the timing of the realization within the boundaries of vesting and expiration. ${ }^{157}$ This is because options are taxed at exercise rather than grant date. ${ }^{158} \mathrm{By}$ deferring taxes, both the company and the executive pay tax at a later date. Doing so allows the amount deferred to grow unhindered until the taxable event at exercise.

153 See I.R.C. $§ 162(\mathrm{~m})$; see also supra Section II.C.1; Section II.C.2; I.R.C. $\S 409 \mathrm{~A}$.

154 I.R.C. $§ 162(\mathrm{~m})$; see also supra Section II.C.2.

155 I.R.C. $\$ 409 A$; see also supra Section II.C.1.

156 The reason that option recipients may defer taxes is because, unlike publicly traded stock, options are difficult to value accurately before exercise.

157 I.R.C. $§ 83($ a). As an example, consider an executive who receives $\$ 100,000$ of restricted stock that vests in three years. At the time of vesting, that $\$ 100,000$ of restricted stock will be treated on the executive's tax return as if they earned that amount in additional salary-and, if the share price climbs, the executive will have a higher tax bill. Furthermore, if the shares pay dividends, the payments will be taxed as ordinary income until the shares vest. After that, they will generally qualify for the $15 \%$ dividend tax rate. If the executive chooses to hold his or her shares after the vesting date, any increase in share price will be taxed as capital gains when they chooses to sell.

$158 I d$. 
From the executive's perspective, the advantage of a tax deferral mimics an exemption from tax on compensation that otherwise would have been received. ${ }^{159}$ That the transaction remains open until the options are exercised results in extraordinarily large amounts of income for the option holders and equally large deductions for the company issuing the options. Thus, the value of the deferral to both the company and the executive will be reflected in higher earnings to the stockholders. The current prevalence of stock compensation causes companies to forego the deferral, which may lower the size of dividends paid to shareholders, reduce earnings per share, and lead to other levels of organizational inefficiency.

\section{Deductions}

While a tax provision can neither prevent companies from paying excessive compensation nor compel a particular compensation structure, it can make it more costly for a company to do what it otherwise would. Section 162(m) encourages the issuance of non-discounted options, since stock grants, unlike option compensation, are not considered "performance-based." ${ }^{60}$ Thus, Section 162(m) can be considered an "option-based" tax code. This becomes problematic when the larger proportion of equity compensation is no longer options, but stock. As discussed, the SEC and other regulators steered companies towards granting a greater proportion of stock, making it increasingly difficult for companies to take advantage of the performancebased exception to Section 162(m). Today, companies generally forfeit what could have been a Section 162(m)

159 See David I. Walker, Is Equity Compensation Tax Advantaged?, 84 B.U.L. REV. 695, 710 (2004).

160 Recall that non-discounted options are those that are issued "atthe-money" (options that are issued with an exercise price equal to the fair market value of the company's stock on the date of the grant). Discounted options are those that are issued "in-the-money" (options with exercise prices less than the price of the underlying stock on the date of the grant). 
deduction in order to meet the accounting requirements under FASB 123(R). ${ }^{161}$

A number of companies today continue to pay compensation that is not deductible under Section 162(m) and consequently increase the company's cost for that item. ${ }^{162}$ Presumably, a company would be better off in the absence of this penalty and other economically inefficient related costs. When a company absorbs the corporate tax and lowers its after-tax profits, the shareholders will initially bear the burden of a smaller after-tax return on their corporate equity. ${ }^{163}$ By 2005, almost fifty percent of American households owned stock, and in 2007, total retirement assets reached $\$ 17.6$ trillion. $^{164}$ Thus, while Congress may have aimed the tax penalties at executives, shareholders bear the burden-including indirect shareholders, who are less wealthy than institutional

161 It is also important to note that prior to the promulgation of FASB 123(R), companies regularly forfeited deductions in order to pay whatever compensation they decided is best. See Steven Balsam \& Qin Jennifer Yin, Explaining Firm Willingness to Forfeit Tax Deductions Under Internal Revenue Code Section 162(m): The Million-Dollar Cap, 24 J. ACCT. \& PuB. POL'Y 300, 321 (2005) (noting that in the mid-1990s, nearly forty percent of corporations admitted to forfeiting deductions because of Section 162(m)).

162 See, e.g., Bebchuk \& Fried, supra note 7.

163 As one example, when Apple Inc. made Tim Cook its CEO in August 2011, it gave him one million shares of restricted stock that vested purely with the passage of time, meaning that it was not performancebased. This grant was valued at $\$ 378$ million at the time that it was made. See Charles Duhigg \& David Kocieniewski, How Apple Sidesteps Billions in Taxes, N.Y. Times (Apr. 28, 2012), http://www.nytimes.com/2012/ 04/29/business/apples-tax-strategy-aims-at-low-tax-states-and-

nations.html [https://perma.cc/CWF7-MH22]. Yet it did not meet the performance-based exception of Section 162(m) and therefore was not deductible. This costs shareholders over $\$ 100$ million in additional taxes at the current tax rate. See also Bebchuk \& Fried, supra note 7, at 46 ("Executive compensation does not hurt shareholders directly; it hurts them indirectly, through their equity interests in the firm.").

164 Joy Sabino Mullane, Incidence and Accidents: Regulation of Executive Compensation Through the Tax Code, 13 LEWIS \& CLARK L. REV. 485, 538 (2009). 
shareholders and consequently more sensitive to fluctuations in their asset values.

\section{Current Tax Reform Legislation}

Congress has introduced numerous pieces of legislation in the past decade seeking to reform tax laws related to executive compensation. These include the Ending Corporate Tax Favors for Stock Options Act, ${ }^{165}$ the Ending Excessive Corporate Deductions for Stock Options Act, ${ }^{166}$ the Stop Subsidizing Multimillion Dollar Corporate Bonuses Act, ${ }^{167}$

165 Ending Corporate Tax Favors for Stock Options Act, S. 2116, 110th Cong. (1st Sess. 2007), https://www.congress.gov/bill/110thcongress/senate-bill/2116/text [https://perma.cc/B8Y2-T3RP] (seeking to decouple the amount of the employer's deduction from the amount of the employee's income inclusion for NQSOs and to eliminate the exemption of NQSOs from the $\$ 1$ million limitation imposed by Section $162(\mathrm{~m})$ ).

166 Ending Excessive Corporate Deductions for Stock Options Act, S. 1491, 111th Congress (1st Sess. 2009) https://www.congress.gov/bill/111thcongress/senate-bill/1491/text [https://perma.cc/X938-PB3R]_(seeking to reconcile the corporate tax benefits based on stock option compensation with the accounting expenses for such compensation). This legislation was prompted by a 2008 investigation that showed that U.S. companies reduced their taxes by billions of dollars by claiming $\$ 52$ billion more in stock option tax deductions than the stock option tax expenses shown on their books. Press Release, Homeland Security \& Governmental Affairs Permanent Subcommittee on Investigations, Senate Investigations Subcommittee Releases New Data on Excessive Corporate Stock Option Deductions Totaling $\$ 52$ Billion (June 16, 2010), https://www.hsgac.senate.gov/subcommittees/investigations/media/senateinvestigations-subcommittee-releases-new-data-on-excessive-corporatestock-option-deductions-totaling-52-billion [https://perma.cc/F33X-VFY3].

167 Stop Subsidizing Multimillion Dollar Corporate Bonuses Act, S. 1476, 113th Cong. (1st Sess. 2013), https://www.congress.gov/bill/113thcongress/senate-bill/1476/text [https://perma.cc/24ZQ-2GJM]. "This legislation would close a major loophole in current corporate tax law by putting an end to unlimited tax write-offs on performance-based executive pay" and calls for a $\$ 1$ million deductibility ceiling on compensation that extends to all officers, directors, and employees. Press Release, Jack Reed United States Senator for Rhode Island, Reed, Blumenthal, Doggett Offer Bill to End Special Tax Exemptions for Huge CEO Bonuses (Jan. 10, 2017), https://www.reed.senate.gov/news/releases/reed-blumenthal-dogget t-offer-bill-to-end-special-tax-exemptions-for-huge-ceo-bonuses 
and the Income Equity Act, ${ }^{168}$ many of which are endorsed by organizations across party-lines. ${ }^{169}$ Yet, these regulations

[https://perma.cc/VXL3-PH2K]. This bill was in response to a study that estimated that the tax deduction for executive compensation under Section $162(\mathrm{~m})$ cost the Treasury $\$ 7$ billion in 2010 alone and $\$ 30.4$ billion between 2007 and 2010. Press Release, Economic Policy Institute, Corporate Tax Deductions for Executive Pay Cost U.S. \$7 Billion in Lost Revenue in 2010 (Aug. 14, 2012), http://www.epi.org/press/corporate-taxdeductions-executive-pay-cost/ [https://perma.cc/R356-E77U]. Note that this bill was assigned to the House Ways and Means Committee and the Senate Finance Committee on April 29, 2015, which will both consider the bill before sending it to the floor for consideration. See also Section 3802 of the Tax Reform Act of 2014, H. R. 1, 113th Cong. (2d Sess. 2014), https://www.congress.gov/bill/113th-congress/house-bill/1/text

[https://perma.cc/V6TZ-2UBU] (seeking to eliminate to the performancebased exemption from the $\$ 1$ million cap for the five highest paid corporate officers).

168 Income Equity Act of 2015, H. R. 1305, 114th Cong. (1st Sess. 2015), https://www.congress.gov/bill/114th-congress/house-bill/1305/text [https://perma.cc/GSG8-4ZR8] (seeking to deny all firms tax deductions on any executive pay that exceeds over twenty-five times the pay of the firm's lowest-paid employee or $\$ 500,000$, whichever is higher, and to set a deductibility cap on all forms of executive pay, which removes the "performance-based exemption" from Section 162(m)). Note that this bill was referred to the House Committee on Ways and Means in March 2015.

169 For example, the Ending Corporate Tax Favors for Stock Options Act, S. 2116, 110th Cong. (1st Sess. 2007) has been endorsed by the Consumer Federation of America, Citizens for Tax Justice, Tax Justice Network-USA, OMBWatch, the Financial Policy Forum, and the ACL-CIO. Press Release, Homeland Security \& Governmental Affairs Permanent Subcommittee on Investigations, Levin Introduces Bill to End Double Standard in Corporate Tax Break for Executive Stock Options (Sept. 28, 2007), https://www.hsgac.senate.gov/subcommittees/investigations/media/ levin-introduces-bill-to-end-double-standard-in-corporate-tax-break-forexecutive-stock-options [https://perma.cc/K3XE-Z9M7]. The other bills mentioned are in similar positions. See e.g., Press Release, Homeland Security \& Governmental Affairs Permanent Subcommittee on Investigations, Senate Investigations Subcommittee Releases New Data on Excessive Corporate Stock Option Deductions Totaling \$52 Billion (June 16, 2010), https://www.hsgac.senate.gov/subcommittees/ investigations/media/senate-investigations-subcommittee-releases-newdata-on-excessive-corporate-stock-option-deductions-totaling-52-billion [https://perma.cc/C73Z-LDSE]; Press Release, Rep. Doggett Calls For End to Tax Write-Off For Exorbitant Executive Bonuses (Jan. 29, 2014) 
have languished in Congress, and based on recent history, it seems unlikely that any have much chance of passage. This continued legislative focus on reforming executive compensation indicates that it is an ongoing matter of public concern. The reforms are often imposed as a reaction to perceived abuses in executive pay or to economic downturns (which are generally associated with increases in income inequality). ${ }^{170}$ Consequently, the regulation is driven by political, rather than shareholder, agendas, which rarely embrace the forward-looking goal of creating shareholder value and instead are prescriptive. As eloquently stated by Senator Chuck Grassley (R-IA) of Section 162(m): "It was well-intentioned. But it really hasn't worked at all. Companies have found it easy to get around the law. It has more holes than Swiss cheese ... These sophisticated folks are working with Swiss-watch-like devices to game this Swiss-cheese-like rule." ${ }^{171}$ Section $162(\mathrm{~m})$ 's aim was to create accountability in executive compensation, yet it spurred companies to evade its requirements through the options industry. New regulations are likely to have a similar effect. Rather than issuing knee-jerk reactions to corporate scandals that intend to shame executives into accepting lower pay, legislators should consider re-examining the

https://doggett.house.gov/media-center/press-releases/rep-doggett-callsend-tax-write-exorbitant-executive-bonuses [https://perma.cc/LQ8DATHR].

170 Note that this correlation is associated with rising levels of unemployment. This Note does not make the claim that income inequality has caused the financial crisis - in fact, the evidence stacks in the other direction. See Michael D. Bordo \& Christopher M. Meissner, Does Inequality Lead to a Financial Crisis? 1 (NBER Working Paper No. 17896, 2012), http://www.nber.org/papers/w17896.pdf [https://perma.cc/NE3MTK86] (arguing that credit booms heighten the probability of a banking crisis, but finding no evidence that a rise in top income shares leads to credit booms).

171 Press Release, Jack Reed, Reed-Blumenthal Introduce the Stop Subsidizing Multimillion Dollar Corporate Bonuses Act (Aug. 2, 2013), http://www.reed.senate.gov/news/releases/reed-blumenthal-introduce-thestop-subsidizing-multimillion-dollar-corporate-bonuses-act [https://perma.cc/ZBX3-6JU2]. 
efficacy of such policies, and whether it might be better for the companies to resolve these agency problems on their own.

\section{CONCLUSION}

For the past few decades, public companies have compensated their senior executives largely with optionswhich are not treated as an expense on the company's books, are tax-favored, and (at least in the short-term) have linked executive pay to firm performance. This trend, however, has shifted in the past ten years: stock grants replaced options as the dominant form of equity pay. This Note presents the first comprehensive study of the change in the equity composition of executive compensation suites after the financial crisis.

The evidence shows that stock grants now comprise the majority share of executive equity pay suites. The movement away from stock options and towards stock grants-in effect, a referendum on corporate risk-taking-cannot be explained away by differences in executive age or firm size. Instead, the increase in the proportion of stock compensation arises from the impact of the panoply of federal efforts to control executive compensation and mitigate risk.

This finding has important implications for investors and regulators who wish to offset managerial influence over executive compensation at public companies. Investors should consider the degree of risk with which they are comfortable and consider contractual efforts to shift CEO incentives towards long-term strategies. Regulators should acknowledge the perverse incentives created by current tax and disclosure laws. Part of the problem is that regulation generally targets fairly narrow elements of compensation, allowing plenty of room for circumvention that comes at a cost to the company and shareholders alike. Additionally, by forcing executive pay to fit neatly into the box of their choosing, regulators have missed the forest for the trees: their focus limits types and amounts of pay, rather than addressing executive incentives. Moreover, the recent rules proposed on executive pay are likely to only aggravate these problems. Regulators should re-examine current policies 
with an eye to realigning executive incentives with those of their shareholders; this may take time, but the quick fixes through the tax code, SEC disclosure requirements, and federal legislation have thus far proven counterproductive or caused unforeseen negative results.

The data presented here cannot speak to the effects of the Dodd-Frank Act, since Section 953(a) will take effect through the forthcoming 2016 schedules. Whether the revised disclosure requirements will lead public companies to follow a historically similar path has yet to be determined. This Note offers an early glimpse into the composition of executive pay after the financial crisis. 